\title{
12. SCHIZOSPHAERELLA DEFLANDRE AND DANGEARD IN JURASSIC DEEPER-WATER CARBONATE SEDIMENTS, MAZAGAN CONTINENTAL MARGIN (HOLE 547B) AND MESOZOIC TETHYS ${ }^{1}$
}

\author{
Otto Kälin, Dipartimento di Scienze della Terra, Università di Pisa \\ and \\ Daniel Bernoulli, Geologisches Institut der Universität Basel ${ }^{2}$
}

\begin{abstract}
The Jurassic (hemi)pelagic continental margin deposits drilled at Hole 547B, off the Moroccan coast, reveal striking Tethyan affinity. Analogies concern not only types and gross vertical evolution of facies, but also composition and textures of the fine sediment and the pattern of diagenetic alteration. In this context, the occurrence of the nanno-organism Schizosphaerella Deflandre and Dangeard (sometimes as a conspicuous portion of the fine-grained carbonate fraction) is of particular interest. Schizosphaerella, an incertae sedis taxon, has been widely recorded as a sediment contributor from Tethyan Jurassic deeper-water carbonate facies exposed on land. Because of its extremely long range (Hettangian to early Kimmeridgian), the genus Schizosphaerella (two species currently described, $S$. punctulata Deflandre and Dangeard and $S$. astrea Moshkovitz) is obviously not of great biostratigraphic interest. However, it is of interest in sedimentology and petrology. Specifically, Schizosphaerella was often the only component of the initial fine-grained fraction of a sediment that was able to resist diagenetic obliteration. However, alteration of the original skeletal structure did occur to various degrees. Crystal habit and mineralogy of the fundamental skeletal elements, as well as their mode of mutual arrangement in the test wall with the implied high initial porosity of the skeleton (60-70\%), appear to be responsible for this outstanding resistance. Moreover, the ability to concentrate within and, in the case of the species $S$. punctulata, around the skeleton, large amounts of diagenetic calcite also contributed to the resistance.

In both species of Schizosphaerella, occlusion of the original skeletal void space during diagenesis appears to have proceeded in an analogous manner, with an initial slight uniform syntaxial enlargement of the basic lamellar skeletal crystallites followed, upon mutual impingement, by uneven accretion of overgrowth cement in the remaining skeletal voids. However, distinctive fabrics are evident according to the different primary test wall architecture. In $S$. punctulata, intraskeletal cementation is usually followed by the growth of a radially structured crust of bladed to fibrous calcite around the valves. These crusts are interpreted as a product of aggrading neomorphism, associated with mineralogic stabilization of the original, presumably polyphase, sediment.

Data from Hole 547B, along with inferences, drawn from the fabric relationships, suggest that the crusts formed and (inferentially) mineralogic stabilization occurred at a relatively early time in the diagenetic history in the shallow burial realm. An enhanced rate of lithification at relatively shallow burial depths and thus the chance for neomorphism to significantly influence the textural evolution of the buried sediment may be related to a lower $\mathrm{Mg} / \mathrm{Ca}$ concentration ratio in the oceanic system and, hence, in marine pore waters in pre-Late Jurassic times.
\end{abstract}

\section{INTRODUCTION}

The Jurassic pelagic and hemipelagic carbonate sediments recovered at Hole 547B, seaward of the Mazagan Plateau (Fig. 1) show many similarities with continental margin deposits of like age from the Mediterranean Tethys. These similarities include sedimentary textures and structures, fossil content, microfacies, ultrastructure of the carbonate matrix, and the overall vertical evolution of facies (Bernoulli and Kälin, this volume). In the carbonate sediments of the Jurassic section of Hole 547B, Schizosphaerella Deflandre and Dangeard, a presumably planktonic, calcareous nanno-organism occurs, sometimes constituting a notable portion of the fine-grained matrix. This taxon, widely recorded as a sediment contributor from exposed Jurassic deeper-water carbonate facies in the Tethyan realm and the adja-

\footnotetext{
${ }^{1}$ Hinz, K., Winterer, E. L., et al., Init. Repts. DSDP,. 79: Washington (U.S. Govt. Printing Office).

2 Addresses: (Kälin) Dipartimento di Scienze della Terra, Università di Pisa, Via Santa Maria 53, 56100 Pisa, Italy; (Bernoulli) Geologisches Institut der Universität Basel, 32 Bernoullistr., CH-4056 Basel, Switzerland.
}

cent expanded epeiric seas, had previously not been reported from Jurassic DSDP cores.

An earlier study (Kälin, 1980) has analyzed the skeletal ultrastructure of the type species Schizosphaerella punctulata and the principal morphologic effects of its diagenesis have been outlined. Furthermore, attention has been drawn to the extraordinary resistance of the skeleton of Schizosphaerella to diagenetic obliteration. This outstanding stability as well as the important role of Schizosphaerella (in particular, S. punctulata) as a nucleation site for large amounts of diagenetic calcite in many Tethyan deeper-water carbonate facies appears attributable to the crystal habit and the mineralogy (presumably stable low-Mg calcite) of the fundamental lamellar skeletal elements. Their arrangement in the test wall with the implied high initial porosity of the skeleton (approximately $60-70 \%$ of the total volume of the skeleton) also appeared to be a contributing factor. This, in turn, raises the problem of the sources of the significant quantities of diagenetic calcite drawn by schizosphaerellids and, hence, of the primary composition of the mud fraction and the general pattern of subsequent diagenetic alteration of fine-grained (micritic) deeper- to 


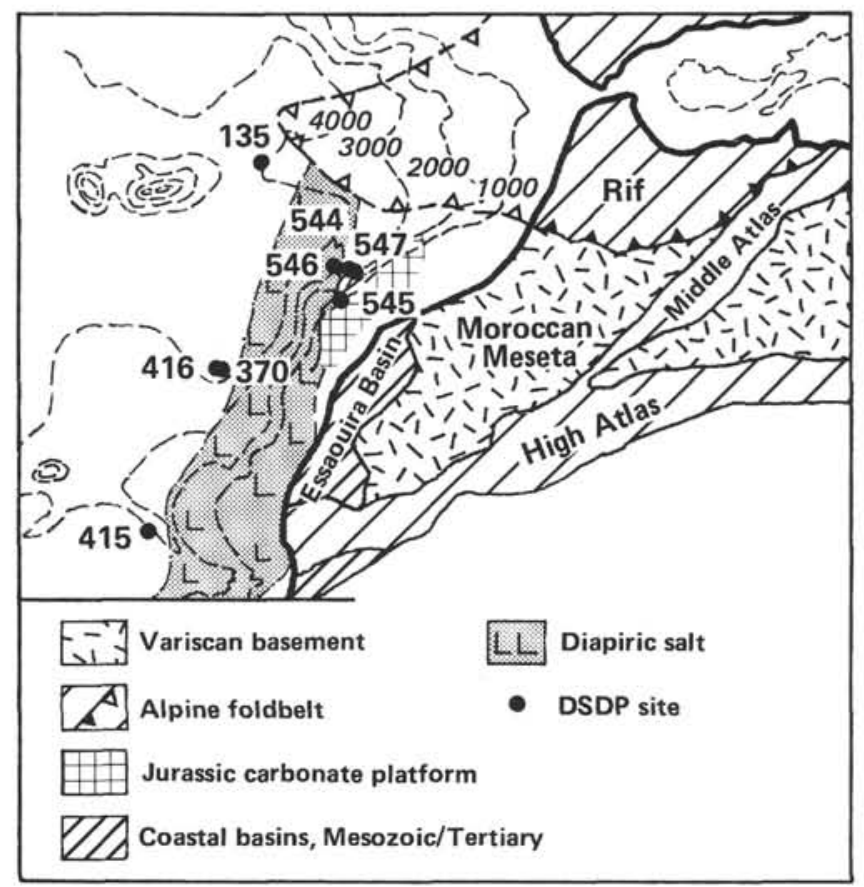

Figure 1. Location and tectonic setting of Deep Sea Drilling sites, Northwest African continental margin.

deep-marine carbonate sediments widely occurring in Jurassic continental margins. Direct evidence is scarce; however, from the general paleogeographic framework, we may presume that the original carbonate lutum had a mixed mineralogical and petrographical composition, including calcitic tests of calcareous plankton and variable amounts of platform-derived fines of diagenetically reactive high- $\mathrm{Mg}$ calcite and aragonite mineralogy (compare Bahamian peri-platform oozes; Schlager and James, 1978). Unlike the Tethyan deep-water limestones, now exposed in the circum-Mediterranean mountain belts, the sediments drilled at Hole 547B have probably never come into contact with freshwater, but have only undergone early cementation at the seafloor or under-sea burial diagenesis. Thus, they should provide the opportunity to establish the nature and degree of possible late diagenetic, freshwater overprint in Tethyan deep-water carbonate rocks, and thereby help to unravel a still largely speculative diagenetic history.

The observations and comments in this paper are intended to complement the results published by Kälin (1980). The examination of additional Tethyan material and of core samples from the Jurassic sequence recovered at Hole 547B permits the diagenesis of Schizosphaerella to be discussed more extensively and some general inferences to be drawn concerning the diagenetic evolution of early Mesozoic deeper-marine carbonates. Additional points we shall touch upon in this study include the skeletal ultrastructure of $S$. astrea (a species recently described by Moshkovitz, 1979) and the systematic position of Schizosphaerella, its stratigraphic significance, and its distribution at Hole 547B.

A detailed review of the previously published work on the still poorly known group of the schizosphaerel- lids will not be presented here as summaries are given by Aubry and Dépêche (1974) and Kälin (1980). Those studies that are pertinent to the problems discussed below will be mentioned where appropriate.

\section{ULTRASTRUCTURE AND SYSTEMATICS}

Schizosphaerella, a Jurassic nannofossil incertae sedis, is a presumably planktonic organism characterized by a roughly globular calcareous test (approx. 10-30 $\mu \mathrm{m}$ in diameter) composed of two interlocking sub-hemispherical valves ranging in thickness from less than $1 \mu \mathrm{m}$ to approximately $3 \mu \mathrm{m}$. In detail, the skeletal gross morphology may vary markedly as might the type of hingement between epi- and hypovalve (Aubry and Dépêche, 1974). Scanning electron microscopy (SEM) revealed that the complex wall ultrastructure of Schizosphaerella is based on only one fundamental structural element, i.e., tiny parallelogram-shaped calcite lamellae, most likely bounded by rhombohedral crystal faces. Their thickness is about $0.1 \mu \mathrm{m}$; their width approximately $0.5-0.7 \mu \mathrm{m}$. The length may vary as a function of valve thickness, as the lamellae extend continuously across the full thickness of the wall and are oriented obliquely to the wall surfaces. This inclination of the elementary crystallites might be related to the original foundation of their small terminal rhombohedral faces on an organic substrate, possibly a basal organic template upon which crystal growth was induced by epitaxy. Moreover, the direction of inclination of the lamellae is not constant. Typically, they assume a specified number of different orientations relative to each other, thus forming an intricate but fundamentally ordered geometric framework. However, anomalous, more or less irregular pattern is frequently observed in the scanning electron micrographs, probably as a consequence of valve curvature. Modeling of the ideal wall ultrastructures proved them to be perfectly realizable only on a plane surface (Kälin, 1980; Pl. 1).

The genus Schizosphaerella presently includes two species: the type species $S$. punctulata, first described in lower Oxfordian marls from Villers-sur-Mer in Normandy and the only recently introduced $S$. astrea, recovered from lower Pliensbachian deposits in the Stowell Park Borehole, Gloucestershire, England (Moshkovitz, 1979). Distinctive features comprise the test wall architecture, in particular, the mode of mutual arrangement of the constituent fundamental lamellar crystallites, the type of hingement, and the dimension of the test. In general, $S$. astrea tends to be larger than $S$. punctulata. An additional criterion, intimately related to the primary ultrastructures of the two taxa, is how their specific fabric is altered by diagenesis (see below).

$S$. punctulata show's a striking variability in test shape and typically has a more refined system of hingement, with the valves most frequently interlocking along a ringshaped groove developed at the periphery of the hypovalve. The wall ultrastructure is based on a rectangular (tetragonal) mutual disposition of the oblique parallelogram-shaped elementary crystallites (Pl. 1, Fig. 1). Such an arrangement causes intergrowth between lamellae that slant in opposite directions with intersections always parallel to the valve surface. As there are four dis- 
tinct systematically recurring orientations of the lamellae, the intersections of pairs of lamellae frame a square reticulation at regular intervals across the test wall. This pattern is usually recognized on both the inner and outer surface of valves in well-preserved specimens of $S$. punctulata (Pl. 1, Figs. 2, 7; for a more detailed description of the structural plan, see Kälin, 1980). In the above ultrastructural scheme, the fundamental skeletal elements define two types of major voids, square-bipyramidal and sphenoidal in shape, which also display a systematic arrangement (Pl. 1, Fig. 3).

$S$. astrea, on the other hand, as described by Moshkovitz (1979), consists of two roughly hemispherical valves fitting over each other in a simple, boxlike manner. Under the SEM they reveal a random surface pattern, with six or five, and sometimes four, vertical tabular crystallites radiating in a starlike pattern from the same point. Moshkovitz further notes that the crystallites usually delimit triangular pores. No material suitable to confirm his observations on the primary skeletal structure was available to us, neither from Tethyan Jurassic facies nor from cores recovered at Hole 547B. However, the sum of evidence derived from our own material, affected to various degrees by diagenetic overgrowth in combination with the data published by Moshkovitz, permits us to establish a tentative, geometrically feasible scheme of the fundamental ultrastructure of $S$. astrea. As can be deduced from Moshkovitz's observation of triangular voids on the valve surfaces of $S$. astrea, the test wall architecture appears to be controlled by a basically triangulate arrangement of the elementary lamellar crystallites. In contrast to Moshkovitz's interpretation, however, the lamellae can clearly be seen to be oriented obliquely with respect to the wall surfaces, analogous to $S$. punctulata. We thus envisage them to occupy three distinct positions relative to each other in the basic ultrastructure and to be interrelated spatially as shown in Plate 1, Figures 4 and 5. Such an interrelationship implies that no intergrowth between lamellae occurs with their progressive increase in length, the resulting framework (Pl. 1, Fig. 8) then being considerably simpler than that of $S$. punctulata. Moreover, the construction of the wall of $S$. astrea causes only one type of major skeletal void to occur. These are rhombohedron-shaped cavities, oriented with their long axes perpendicular to the valve surface (Pl. 1, Fig. 6). An apparently more frequent deviation in $S$. astrea from the ideal ultrastructural pattern may occur because, in the proposed structural scheme, the lamellae do not interpenetrate. Hence, there was possibly some scope for movement, in particular with incipient overgrowth after decay of the presumed original organic matrix.

\section{POSSIBLE BIOLOGICAL AFFINITY}

A major unsolved problem with Schizosphaerella concerns its biological affinity. Deflandre and Dangeard (1938) have already stated in their initial description of the genus that there is a striking morphological resemblance to diatoms because of the presence of two interlocking valves. In particular, a similarity to presumed Liassic diatoms of the genus Pyxidicula Ehrenberg has been stressed. However, a close biological affinity has been seriously questioned (Dangeard, 1942; Deflandre, 1954; Aubry and Dépêche, 1974); at first, because of the different mineralogy of the skeleton and then as more detailed information became available, because of the distinctive skeletal ultrastructure. An additional argument against such an affinity concerns the life cycle and, specifically, the mode of reproduction of diatoms. Diatoms, for the most part, reproduce asexually by separation of the two boxlike joined valves (larger, outer epitheca and smaller, inner hypotheca) and subsequently form two new individuals, always with the development of new hypothecas. Hypothecas of a given generation thus assume the function of epithecas at maturity (Burckle, 1979). However, in the majority of the known morphotypes of Schizosphaerella, the epi- and hypovalve differ not only with regard to gross morphology, but also with respect to the structure of the peripheral areas of the valves. In fact, they differ to such a degree that interchangeability may be ruled out.

However, an assignment to coccolithophorids also does not seem plausible for morphogenetic reasons. Assignment appears to be precluded because of the well-established intracellular formation of coccoliths. Extrusion of the structural units of the coccosphere to the periphery of the cell is accomplished only after development is completed. From there they may then be dislodged and shed from the cell as more coccoliths are produced (Wilbur and Watabe, 1963; Pautard, 1970). In contrast, the principles of construction established for the test wall of Schizosphaerella (particularly, S. punctulata with the systematically recurring intergrowth between the constituent basic lamellar crystallites; see above) point to an in situ formation of the skeleton, probably along the cell's periphery.

Because of the confusing taxonomy, discussion of a possible relationship of Schizosphaerella with Mesozoic calcispheres requires a short review of the current opinions concerning their classification and affinities. The incertae sedis family Calcisphaerulidae, as redefined by Villain $(1975 ; 1977)$, includes a number of exclusively Cretaceous (Albian to Maastrichtian) spherical to ovate forms, usually ranging in size from $20-300 \mu \mathrm{m}$. These forms normally possess one aperture and have, as a common diagnostic feature, a wall composed of radiating calcite fibers, presumably interspaced originally by an organic matrix. The fibers are inclined with respect to the wall surfaces, with the angle of inclination depending on shell curvature. However, unlike in Schizosphaerella, the direction of inclination of the elementary crystallites is basically uniform. Calcification of the test wall is thought to extend from around the aperture and the growth of the individual fibers, in turn, occurs centripetally, inward from both surfaces of the test wall. Syntaxial overgrowth during early diagenesis would cause the elementary fibers to thicken until they attached to each other and to increase in length beyond the original limits of the shell. Based on the detailed spatial arrangement of the fundamental skeletal elements with respect to the axis of the skeleton, deduced mainly from the patterns observed at shell surfaces, Villain $(1975 ; 1977)$ distin- 
guishes two major groups: the Pithonellomorphs and the Bonetocardiellomorphs, comprising the genera $\mathrm{Pi}$ thonella, Palinosphaera and Bonetocardiella, Asterosphaerella, respectively. Calcisphaerulid test organization as well as wall architecture is, according to this author, reminiscent of calpionellids (Aubry et al., 1975), possible ancestors in his view.

On the other hand, Masters and Scott (1978) subdivided Mesozoic calcispheres into three families, on the basis of the three fundamental types of wall ultrastructure distinguishable by SEM. These are (1) the emended family Cadosinidae Wanner (1940), characterized by a single-layered wall that consists of numerous tiny calcite platelets generally oriented parallel to the wall surface and, at lower magnifications, reveals a granular texture that is due to the small size of the platelets; (2) the family Stomiosphaeridae Wanner (1940), also revised by the authors, with a single-layered wall constructed of radially arranged calcite prisms; and (3) the newly introduced family Bonetocardiellidae Masters and Scott (1978) exhibiting a lamellar original structure, made of several, approximately $0.7 \mu \mathrm{m}$ thick, calcite blades oriented subparallel to the wall surface. Because of its radial wall structure, Bonetocardiella sensu Villain has been transferred to the new genus Inocardion and as such has been included, together with Pithonella, in the family Stomiosphaeridae. Many structural features reported by previous authors that seem to depart from these three fundamental types could feasibly be interpreted by Masters and Scott (1978) as either effects of diagenesis or simply due to acid etching during sample preparation. As for the biological affinities of the Mesozoic calcispheres, Masters and Scott argue for a relationship to algae. In particular, they interpret the calcispheres as reproductive cysts of some extinct dasycladacean group.

It is obvious that, apart from the general test morphology and the significantly larger dimension of the Calcisphaerulidae, substantial differences in the ultrastructure prohibit including Schizosphaerella within one of the above calcisphere taxa. On the other hand, Bolli (1974) placed a number of Upper Jurassic and Cretaceous forms (40-70 $\mu \mathrm{m}$ in diameter) as new species within the calcisphaerulid genus Pithonella Lorenz (1901). These new forms partly displayed ultrastructural features reminiscent of Schizosphaerella. Scanning electron micrographs of wall cross sections of the species $P$. johnstohni, P. quiltyi, and P. patriciagreeleyae (Bolli, 1974, pl. 6 , fig. 8 ; pl. 17 , figs. 7,12 ; pl. 2 , fig. 12 ) reveal a complex pattern of calcite prisms or laths (partially delimited by rhombohedral crystal faces) oriented obliquely to the surfaces of the test wall and slanting in different directions, hence resulting in a crosswise mutual arrangement. In some cases, crystallites can be seen to extend across the full thickness of the wall. Based on our experience with Schizosphaerella, we agree with Masters and Scott (1978) that the rather tight crystal fabrics described by Bolli are unlikely to represent original, biologically secreted structures, but are largely diagenetic. They presumably reflect more or less advanced stages in a process of alteration governed by accretion of syntaxial overgrowth cement. However, as diagenetic overgrowth does not normally occur at random, but is controlled by the original skeletal architecture, we must conclude that the forms in question differed significantly regarding their skeletal structure from Pithonella, as conceived by previous authors and revised by Villain $(1975 ; 1977)$ and Masters and Scott (1978). In view of the general significance of skeletal ultrastructure for the classification of organisms, Bolli's loose taxonomic concept of the Calcisphaerulidae and, particularly, of the genus Pithonella may thus appear debatable. Based on the presence in each species of forms with and without aperture, Bolli also interprets calcisphaerulids as cysts, possibly algal. Furthermore, he points out similarities to Thoracosphaera without, however, advancing an opinion on the systematic position of the latter.

By comparing gross morphology and wall ultrastructure of well-preserved representatives of the Pithonella group (sensu Bolli, 1974) to that of systematically ascertained calciodinellids, Keupp (1979) succeeded in providing conclusive arguments in favor of an interpretation of the Pithonella forms described by Bolli as cysts of calcareous dinoflagellates. With the subsequent finding (Keupp, 1980) in a number of specimens of Pithonella patriciagreeleyae Bolli of a complete inside paratabulation that largely reflected the thecal tabulation of the modern Peridinium trochoideum, the definite proof for such an interpretation was furnished. We will not address the question here of whether or not Bolli's (1974) systematic treatment of the Calcisphaerulidae (and whether or not the full spectrum of forms since attributed to the single genus Pithonella shares this same systematic position) is correct. Nevertheless, it is now clear that the ultrastructural type with complexly crossing elongate calcite crystallites (referred to by Keupp $(1979 ; 1980)$ as "Kreuzbalken-Struktur") reminiscent of Schizosphaerella is a structure that is realized in calcareous dinoflagellates. Thus, an affinity of Schizosphaerella to this group is suggested. The same natural affinity has, in fact, been suspected also by Moshkovitz (1979). Moshkovitz stressed the architectural similarities between the test wall of Schizosphaerella astrea and Thoracosphaera tesserula Fütterer, a taxon of the thoracosphaerids which similarly have recently been attributed systematically to the calcareous dinoflagellates and placed in proximity with the calciodinellids within the Peridiniales (Fütterer, 1976; 1977; Jafar, 1979)

However, a major distinctive feature remains. The fundamentally ordered nature of the skeletal structure in Schizosphaerella appears to have no counterpart among the presently known structural types occurring in calcareous dinocysts. Rather, primary "Kreuzbalken"-wall structures of calcareous dinocysts (such as those presented by Keupp, 1979, pls. 3-6) typically reveal a prominent competitive growth pattern, with the fundamental oblique crystallites diminishing in number and increasing in size away from the inner delicate organic membrane, upon which calcification initiated, probably in an organized way. This suggests that in dinocysts there is, after nucleation, probably no further direct biological control on crystal growth. Nevertheless, we do not exclude the possibility that smooth outer shell surfaces with plane distal 
crystal terminations may depend on the original presence of an additional outer organic layer that ultimately limited growth, as presumed by Keupp (1979). By contrast, skeletal architecture in Schizosphaerella does not normally vary with increasing wall thickness. Valves of different overall thickness, as are commonly found among specimens of the same population, generally reveal identical surface morphology, i.e., the fundamentally square or triangulate reticulate pattern recurring at regular intervals across the valve with continued lengthwise growth of the basic skeletal elements (Pl. 1). We thus think that in the case of Schizosphaerella the elementary crystallites were encased in an organic matrix that exerted a controlling influence on their habit, orientation, and rate of increment throughout the entire growth of the skeletal system, with the different valve thicknesses reflecting distinct growth stages. Clearly, these inferences call into question an interpretation of Schizosphaerella as calcified cysts of some peridinoid dinoflagellate. Rather, they seem compatible with a peripheral, stabilizing, and, possibly, protective mineralized structure of a cell in the vegetative life phase. This, however, does not necessarily preclude an allocation of Schizosphaerella to dinophyceans. Tangen et al. (1982) demonstrated that in the case of Thoracosphaera heimii (Lohmann) Kamptner (1920), the type species of Thoracosphaera Kamptner (1927), the globular calcified cell wall does not belong to the cyst stage but is a shell for the organism in the main vegetative phase of its life cycle. Consequently, these authors proposed the introduction of the Thoracosphaerales, a new dinoflagellate order, intended to embrace predominantly coccoid, marine planktonic dinophytes having a calcified cell wall in their vegetative life phase. We are aware that information coming from the fossil record alone is probably insufficient to establish the true affinity of Schizosphaerella. However, based on the data presently available, we think that Schizosphaerella is best placed within this new order in an independent group, beside the family Thoracosphaeraceae as emended by Tangen et al. (1982).

\section{STRATIGRAPHIC SIGNIFICANCE AND OCCURRENCE AT HOLE 547B}

Schizosphaerella is extremely long-ranging among the Jurassic calcareous nannofossils and, as such, is obviously not of great help for detailed stratigraphic interpretations. Nevertheless, in those cases where other, more diagnostic fossils are lacking in the record or where these fossils are not preserved because of either depth-controlled selective dissolution or obliteration with progressive diagenesis, the recognition of Schizosphaerella, feasible even in conventional thin sections, may prove relevant. Moreover, a considerable diversity of morphotypes, typically observed in organic carbon-rich sedimentary facies where schizosphaerellids have undergone only minor diagenetic alteration (e.g., lower Toarcian Schistes Carton, southern France; Oxfordian marls, Villes-surMer), suggests that further studies and delineation of clear taxonomic concepts will possibly improve the biostratigraphic potential of this fossil group. However, giv- en the present state of knowledge, Schizosphaerella is essentially of interest in sedimentology and petrology.

In their original description, Deflandre and Dangeard (1938) reported the type species $S$. punctulata as occurring in strata of middle Bajocian to early Oxfordian age (Mariae Zone) in Normandy. A few years later, it was also found in Liassic deposits (Dangeard, 1942) and in various other locations outside the type area. Lezaud (1967) confirmed the presence of $S$. punctulata in samples of lower Kimmeridgian sediments from Baie de Seine followed by Black (1971) and Amezieux (1972), who found $S$. punctulata in established Hettangian deposits at Pinhay Bay (Dorset) and in the Paris Basin, respectively. A vertical distribution encompassing almost the entire Jurassic period was established. In fact, the total range of the species $S$. punctulata, as established by Medd (1979; 1982), who considered all the British material so far examined from both boreholes and surface localities, comprises a time-stratigraphic interval extending from the Planorbis Zone (base Hettangian) to the Cymodoce Zone (early Kimmeridgian).

With regard to the stratigraphic range of the species $S$. astrea, we are, for the present, left only with the data provided by Moshkovitz (1979) from samples from the Stowell Park borehole (Gloucestershire) and from some additional Jurassic localities in England. The interval this material covers ranges from the early Sinemurian (Bucklandi Zone) to the early Pliensbachian (middle part of Ibex Zone). However, in the description of S. astrea, Moshkovitz (1979) cites among the synonyms a specimen figured by Aubry and Dépêche (1974, pl. 3, fig. 7, light micrograph) which ought to be of much younger age given that these authors only reexamined schizosphaerellids from the lower Oxfordian marls of the type locality Villers-sur-Mer. In fact, as the morphological characteristics of this latter specimen match those of the holotype of S.astrea, the stratigraphic distribution reported from the British type section seems to be far from reflecting the effective range of the species.

In the framework of our sedimentological investigations of Jurassic carbonate facies from the Tethyan realm, centered so far mainly on basinal sequences, we have encountered Schizosphaerella as a common rock constituent in deposits of Sinemurian to late Middle Jurassic age. The occurrence of the species $S$. astrea is apparently restricted to the late Sinemurian to early Pliensbachian (Carixian) interval (Bernoulli and Jenkyns, 1970; Bernoulli and Renz, 1970; Kälin et al., 1979; Kälin and Patacca, unpubl. data). Occasionally, one of the two species may become extremely abundant in which case the sediment shows a prominent pelleted texture in thin section (Pl. 4, Fig. 1). However, there is usually sufficient evidence for such rises in frequency to be attributed to hydrodynamics rather than to environmental changes or even temporary blooms. Whereas the lack of records from the earliest period of the lifespan of Schizosphaerella in the Tethyan realm simply reflects a gap in information, its disappearance by the end of the Middle Jurassic correlates in basinal settings with the installation of essentially siliceous, radiolarian-dominated sed- 
imentary facies. Inferred depositional depths of these sediments close to and below the calcite compensation depth (CCD), which causes carbonate particles to be largely eliminated, is the most obvious explanation. Besides, we suspect that the occurrence of Schizosphaerel$l a$ was favored by extensive shelf areas and epeiric seas, and that, with the gradual establishment of oceanic deepsea environments, relative abundance declined in the central Tethyan realm towards the end of the Middle Jurassic. Hence, disappearance must not necessarily be related to dissolution alone. This seems to be supported by the apparent absence of Schizosphaerella from any of the other DSDP sites that yielded Upper Jurassic sediments, although the facies of these deposits generally suggests that preservation should have been possible. A number of samples of presumed Oxfordian/Kimmeridgian fossiliferous pelagic marls and limestones from the Atlantic (DSDP Sites 105 and 367) proved invariably barren of Schizosphaerella (Kälin, 1980). However, the reliability of the ages assigned to the lowermost cores recovered at these sites has been questioned repeatedly. Even new biostratigraphic data based on radiolarians (Baumgartner et al., 1980; Kocher, 1981) seem to provide no conclusive evidence as to the presence of the Oxfordian and early Kimmeridgian in Hole 367.

For the present study, some 60 samples from the Jurassic sequence drilled at Hole 547B have been checked for the presence of Schizosphaerella, both in thin section and in fresh broken rock surfaces under the SEM. The results of this examination are summarized in Figure 2. Furthermore, in Figure 3 in Bernoulli and Kälin (this volume), the inferred vertical distribution of Schizosphaerella is drawn relative to the occurrences established from some additional fossil groups, also known to contribute to the sediment in deeper- and deep-marine environments of the Tethyan-Atlantic system during the Jurassic period. Schizosphaerella occurs almost continuously from the top of Core 547B-23 through Core 547B-8. Upsection, Schizosphaerella could be identified in various samples of Core 547B-7, and a single undoubted specimen, possibly reworked, has even been found in Core 547B-6 (Sample 547B-6-3, 139-142 cm). Representatives of the species $S$. astrea, normally co-occurring with $S$. punctulata, appear to be restricted to the lower part of the sequence studied, probably to the Sinemurian-lower Pliensbachian (Carixian) interval (Riegraf et al., this volume). This corresponds with the data available so far from sections obtained on land.

The appearance of Schizosphaerella at Hole 547B is unlikely to be chronologically significant as it appears to coincide with a major environmental change, i.e., the drowning of a clastic-dominated, shallow water environment. On the other hand, there is, in the case of the sedimentary sequence recovered at Hole 547B, no reason to believe that factors such as depth-controlled or diagenetic dissolution influenced its disappearance. In fact, the sporadic schizosphaerellids encountered in the core intervals 547B-7-3 to 547B-6-3 are associated with typical Late Jurassic faunal elements (Fig. 3, in Bernoulli and Kälin, this volume).

\begin{tabular}{|c|c|c|c|c|c|c|c|c|c|c|}
\hline \multirow{2}{*}{ Core } & \multirow{2}{*}{$\begin{array}{c}\text { Section } \\
\text { (range in cm) }\end{array}$} & \multicolumn{2}{|c|}{$\begin{array}{l}\text { Method } \\
\text { of study }\end{array}$} & \multicolumn{6}{|c|}{$\begin{array}{l}\text { Presence of Schizosphaerel/a } \\
\begin{array}{cc}\text { S. punctulata } & \text { S. astrea }\end{array}\end{array}$} & \multirow{3}{*}{ 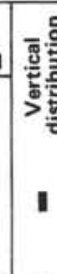 } \\
\hline & & LM & SEM & LM & SEM & LM & SEM & LM & SEM & \\
\hline 6 & $\begin{array}{l}2,97-100 \\
2,148-150 \\
3,94-97 \\
3,136-138 \\
3,139-142 \\
4,0-3 \\
4, C C\end{array}$ & : & " & $\begin{array}{l}a \\
a \\
a \\
\text { a } \\
\text { a } \\
? \\
\text { a }\end{array}$ & $\begin{array}{l}\text { ㅁ } \\
0 \\
0\end{array}$ & $?$ & & & & \\
\hline 7 & $\begin{array}{l}1,47-49 \\
2,25-27 \\
2,146-148 \\
2,148-150 \\
3,29-31 \\
3,49-51 \\
3,81-84 \\
3,115-118 \\
4,86-88\end{array}$ & : & . & $\begin{array}{l}\text { ? } \\
\text { ? } \\
\text { ? } \\
? \\
\text { ? } \\
\text { ? }\end{array}$ & $\begin{array}{l}? \\
? \\
?\end{array}$ & $?$ & & & & \\
\hline 8 & $\begin{array}{l}1,15-17 \\
1,35-37 \\
1,65-69 \\
1,80-83 \\
2,0-3 \\
2,59-62 \\
2,121-124 \\
3,24-27 \\
3,40-43 \\
3,54-57 \\
3,62-65 \\
4,43-46\end{array}$ & $\begin{array}{l}\text { : } \\
. \\
. \\
.\end{array}$ & $\begin{array}{l}. \\
. \\
. \\
.\end{array}$ & $\begin{array}{l}\text {. } \\
\text {. } \\
. \\
\text {. }\end{array}$ & $\begin{array}{l}? \mathbf{4} \\
? \\
? \\
? \\
? \\
4\end{array}$ & $\begin{array}{l}\text { ? } \\
\text { ? }\end{array}$ & & & & \\
\hline 9 & $\begin{array}{l}1,119-121 \\
2,24-28 \\
2,106-109\end{array}$ & & - & $\begin{array}{l}0 \\
0 \\
0\end{array}$ & & & & & & \\
\hline 10 & $\begin{array}{l}1,131-132 \\
3,0-3 \\
3,89-91 \\
3,131-134 \\
4,30-32 \\
4,57-58\end{array}$ & $\begin{array}{l}\text {. } \\
\text { a }\end{array}$ & 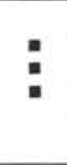 & $\begin{array}{l}\text {. } \\
\text { - } \\
\text { - }\end{array}$ & $?$ & $?$ & $?$ & $?$ & & \\
\hline 11 & $\begin{array}{l}1,127-129 \\
3,66-68 \\
3,92-94 \\
4,118-120\end{array}$ & & : & - & $\begin{array}{l}? \\
? \\
4 \\
4\end{array}$ & & $?$ & & $?$ & \\
\hline 12 & $\begin{array}{l}1,7-9 \\
2,25-28 \\
2,46-48\end{array}$ & & : & & 물 & & & - & $?$ & \\
\hline 13 & $1,141-143$ & - & - & $\Delta$ & $\Delta$ & $?$ & & $?$ & & \\
\hline 14 & $1,144-146$ & - & - & 0 & $\Delta$ & & $?$ & & $?$ & \\
\hline 15 & $\begin{array}{l}1,23-25 \\
1,109-111 \\
2,71-73\end{array}$ & a & 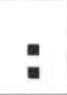 & : & : & - & ? & ? & : & \\
\hline 16 & $\begin{array}{l}1,67-69 \\
2,16-19 \\
2,126-128\end{array}$ & a & 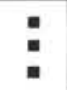 & $\begin{array}{l}1 \\
0 \\
1\end{array}$ & : & & 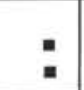 & a & : & \\
\hline 17 & $1,79-83$ & - & - & $\bullet$ & $\bullet$ & - & - & - & - & \\
\hline 19 & $1,121-123$ & - & - & 0 & - & & - & - & & \\
\hline 20 & $20, \mathrm{cc}$ & & - & & $?$ & & & & & \\
\hline 21 & $\begin{array}{l}1,106-108 \\
1,136-138\end{array}$ & & - & & a & & & & & \\
\hline 22 & $\begin{array}{l}1,119-121 \\
2,30-34 \\
2,74-76 \\
2,110-113\end{array}$ & & 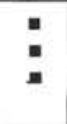 & $\begin{array}{l}\circ \\
: \\
\circ\end{array}$ & : & $\begin{array}{l}\text { ? } \\
\text { ! }\end{array}$ & ? & : & ? & \\
\hline 23 & $\begin{array}{l}2,39-41 \\
2,57-59\end{array}$ & & . & 0 & $\begin{array}{l}0 \\
0\end{array}$ & - & - & & - & \\
\hline . & $\begin{array}{l}\text { arved } \\
\text { imon }\end{array}$ & & $\begin{array}{l}\text { Not o } \\
\text { Abun }\end{array}$ & $\begin{array}{l}\text { bserve } \\
\text { dant }\end{array}$ & & $?$ & $\begin{array}{l}\text { Questio } \\
\text { Displace }\end{array}$ & $\begin{array}{l}\text { onable } \\
\text { ed or }\end{array}$ & rework & \\
\hline
\end{tabular}

Figure 2. Stratigraphic distribution of Schizosphaerella, Hole 547B. Not all samples were studied in the same detail; frequency indications are partial approximations. As indicated by the question marks, unambiguous specific determinations were not always possible. 


\section{PRESERVATION OF SCHIZOSPHAERELLA IN TETHYAN FACIES AND AT HOLE 547B}

\section{Diagenesis of Schizosphaerella punctulata}

The mode of postdepositional alteration of the inferred primary skeletal ultrastructure of $S$. punctulata has been analyzed by Kälin (1980), on the basis of the spectrum of preservational styles found in various deeper-water carbonate facies, mainly of the Tethyan realm. The various diagenetic morphotypes observed can be feasibly interpreted as more or less advanced stages of a single transformative process, divisible into three generally sequential principal phases with possible overlapping. The morphologic changes pertinent to these three phases are illustrated in Plates 2 and 3 and they may be outlined as follows:

1. Decay of the presumed organic matrix encasing the skeletal elements and subsequent conversion of the original, biologically secreted structure into a more or less tight-fitting frame (Pl. 2, Figs. 1-5). The increment in size of the elementary lamellar crystallites required to fasten the original, structurally determined interspaces between them (Pl. 1, Figs. 1, 2, 7) was most likely achieved by simple outward progression of their laterally delimiting rhombohedral faces (see "Ultrastructure and Systematics," earlier).

2. Occlusion of the main skeletal void space through continued deposition of syntaxial overgrowth cement on the remaining free surfaces. In this way, the square-bipyramidal and sphenoidal intra-skeletal voids (PI. 1, Fig. 3) become progressively reduced, and finally filled by inward growth from their confining eight or four sides, respectively. Similarly, the surface morphology with the juxtaposed four-sided pyramidal cavities is smoothed (compare models in Figs. 2, 7 on Pl. 1 and SE micrographs, Figs. 2-4 on Pl. 2, with Figs. 1, 2 on Pl. 3). The volume of diagenetic calcite needed for a thorough cementation of the skeletal voids can be estimated to be approximately twice that of the original biogenic calcite. In detail, the fabrics observed (particularly at valve surfaces as in Figs. 1 and 2 on Pl. 3) indicate that accretion of void-filling syntaxial cement has usually not proceeded in a strictly uniform manner from all the sides defining an individual void. Though the overgrowths founded on the different surfaces appear at their exposed and initially freely growing surfaces to be commonly bounded by equivalent rhombohedral crystal faces (most likely coinciding with those enclosing the original lamellar skeletal elements), they may differ notably in size and shape. This suggests that nucleation was not exactly contemporaneous and that growth probably did not always proceed at identical rates. In spite of this irregular, obviously competitive development, overgrowth does not cause complete obliteration of the diagnostic square-reticulate initial surface pattern, as long as it occurs within the bounds of the original skeletal framework. Only when overgrowth is allowed to expand somewhat beyond the surface of a valve (e.g., due to delayed onset of fringe formation, see (3) below), and competition is therefore no longer restricted merely to the cement crystals involved in the filling of a single void, a random mosaic of intergrown crystals with no obvious relation to any primary structural feature develops, dominated by crystals favored in growth by orientation and early nucleation (Pl. 3, Fig. 3; Pl. 5, Fig. 4). Cross sections of fully cemented valves reveal a tight fabric of more or less equant, polyhedral crystals, sometimes with slightly curved interfaces, or of interfering oblique pillarlike crystals, representing fused cemented void-spaces and skeletal elements. Interfaces are compromise-boundaries and crystal faces. From breakage along crystal faces (cleavage) and disintegration along compromise-boundaries, an accumulation of 0.5 to $1 \mu \mathrm{m}$-sized micrite, frequently observed in scanning electron micrographs of fresh broken sample surfaces of Schizosphaerella-bearing lithologies, may result (e.g., Pl. 6, Figs. 4-5).

3. Crust development around the valves of radiallyoriented bladed to fibrous calcite prisms joined together. Fringing prisms always display sharp and usually plane proximal terminations, suggesting that they do not share the lattice orientation of their foundation (e.g., Pl. 2, Figs. 4, 6; Pl. 3, Figs. 4, 5). Nevertheless, the typically uniform, squarish cross section of the prismatic crystals at their proximal ends and their frequently observed regular arrangement (with the intercrystalline boundaries defining a square grid parallel to the original reticulate surface pattern of the valve, Pl. 1, Fig. 2) gives clear evidence of the substratum's influence on the origin of this fabric. It is interesting that prisms are plane-based and arranged in the described manner not only where their direct substrate was most probably represented by a fully cemented smooth valve surface (e.g., Pl. 5, Figs. 1, 2 ), but also where the underlying valve had undergone only incomplete intraskeletal cementation. Figure 4 on Plate 2 shows such an example, with relic voids occurring between the partially cemented skeletal frame and the smooth inner surface of the overlying crust. The inference in this case is that initial crystal nucleation took place on a preserved peripheral organic membrane. The crust then impeded completion of intraskeletal cementation by virtually isolating the skeletal voids from ambient pore waters. Distally, the crusts are also normally clearly parted from surrounding micrite and (micro) spar. The constituent prismatic crystallites are dominantly square-ended (e.g., Pl. 3, Figs. 4, 5), but in some cases reveal obtuse-rhombohedral terminal crystal faces. Because of valve curvature, calcite prisms based on outer (convex) surfaces gradually increase in width away from the foundation, whereas those on inner (concave) surfaces taper. Widening is often accompanied by a change in shape, with a tendency for the columnar crystals to take on a hexagonal cross section. Prisms are not generally straight-sided, but display along their length alternate shallow obtuse-angled re-entrants and slight bulges (Pl. 3, Fig. 5). This gives the boundaries between adjoining crystals a gently undulating or zigzag line, uncommon for simple compromise boundaries (for example, those developed between primary cement crystals growing into an open space). There is, in fact, no evidence suggesting that competitive growth occurred among individual prisms during formation of the fringes. Only in rare cases, where the fringing crusts were found to de- 
velop outward into a stellate structure of (?neomorphic) (micro)spar (Pl. 3, Fig. 6), did this obviously take place with a reduction in the number of crystals in the fabric, implying that part of the prisms in the inner fringe became crowded out (cf. "pseudo-drusy" fabric of Kendall and Tucker, 1973). Because of the small crystal sizes involved and the difficulty in differentiating individual calcite prisms, their optical orientation cannot be clearly discerned often. However, evidence supports a general length-fast character, with roughly coinciding c-axial and elongation directions. Such an orientation is similarly suggested by the obtuse-rhombohedral crystal terminations occasionally observed. The thickness of the crusts may vary widely between different specimens, but generally it is strikingly uniform around a single valve. Exceptions (in the lithologies studied) appeared to have originated almost exclusively with impingement during growth of one fringe upon another, especially in the case of closely spaced or interlocking valves. The volume of a crust may exceed that of the underlying valve by a factor of 10 to 15 . This implies that this type of diagenetic calcite may, in Schizosphaerella-rich sediments, amount to a substantial portion of the total rock volume (approximately $25 \%$ in the case of the limestone shown in Pl. 4, Fig. 8). The normally isopachous development of the envelopes clearly is incompatible with an interpretation of this fabric as a mere product of direct passive precipitation (palisade cement, e.g., Schroeder, 1972a; $1972 b$ ). With progressive growth of the envelopes, sediment particles originally in direct contact with the valves must have been removed, either mechanically or chemically. This suggests that displacive crystallization (Folk, 1965 ) occurred where crystals were not allowed to grow freely into inter-particle pores or alternatively, that the fringes developed by in situ neomorphic replacement of enclosing carbonate mud, probably by microscale dissolution-reprecipitation across a thin film of fluid. Fabric evidence is not conclusive; rather it suggests that still other mechanisms have to be considered. By analogy with the complex genetic history recently inferred for a number of comparable calcite mosaics in ancient limestones (Kendall and Broughton, 1978; Mazzullo, 1980 and references therein), the calcite fringes might have replaced an earlier form of a radial fibrous or bladed precursor fabric of magnesian calcite or ?aragonite, subsequently stabilized or inverted to (low-magnesian) calcite. If we assume a virtual constancy of ocean chemistry through time, in fact, initial precipitation in the form of one of these metastable polymorphs in the marine phreatic zone and/or the shallow burial realm would seem likely in view of (1) a presumably multiphase original mineralogic composition of the carbonate sediment; (2) probably moderate depositional depths, in the order of $100(\mathrm{~s})$ to $1000 \mathrm{~m}$; and (3) a possibly somewhat restricted depositional environment, with warmer and more saline than normal bottom waters (cf. Schlager and James, 1978; James and Ginsburg, 1979). If we suppose that, in this latter interpretation, the precursor fabric originated as a true (passively precipitated) cement, this fabric had to be irregularly developed, with the constituent crystals locally stunted by impinging grains and pos- sibly with entrapped tiny sediment particles. Perfection of the fabric must then have been the work of later neomorphism; the isopachous and smooth-surfaced envelopes actually observed consequently include portions replacing cement as well as sediment.

\section{Diagenesis of Schizosphaerella astrea}

In Schizosphaerella astrea, modifications with respect to the original skeletal framework proved to be exclusively due to precipitation of secondary overgrowth cement on the constituent lamellar calcite crystallites. Clear effects of dissolution were not recognized in any case. Deposition of cement, moreover, appears to have proceeded in a manner analogous to that outlined above, with an initial slight uniform enlargement of the individual skeletal elements. This enlargement is followed, after mutual impingement, by a phase of uneven extension into the remaining main skeletal voids which tends to terminate in a complete elimination of the primary intraskeletal pore space. However, the fabrics originating from intraskeletal cementation are distinctive, each following a different initial test wall architecture and hence, the different shape and spatial arrangement of the major skeletal voids (Pl. 1, Figs. 6, 8). In obvious contrast to $S$. punctulata, wall cross sections of fully cemented specimens of $S$. astrea resolve under the SEM into aggregates of minute, dominantly rhombohedronshaped crystals stacked one upon another, in the manner exhibited by Figure 6 on Plate 1 (compare Pl. 4, Figs. 4, 6 to Pl. 3, Figs. 4, 5). Furthermore, secondary syntaxial overgrowth in $S$. astrea results in a characteristic ragged surface morphology, both on the inner and outer sides of the valves. The individual projecting crystals typically reveal three-sided pyramidal terminations (see Pl. 4, Fig. 5; Pl. 6, Fig. 2 for an incipient stage of development). A possible explanation for this pattern is that cementation in the case of surficial cavities was not restricted to a mere filling, but tended to complement the incomplete rhombohedral forms defined by the elementary lamellar crystallites (Pl. 1, Fig. 5) outward, beyond the original valve surfaces. A third (and probably the most salient) distinction between the two species is the apparent absence in $S$. astrea of fringing crusts of radial fibrous or bladed calcite, such as described under (3) above. At first, with data derived exclusively from a highly oxidized condensed cephalopod-crinoid limestone (upper Sinemurian, Monte Cetona, southeastern Tuscany) bearing clear evidence of early seafloor lithification (e.g., Pl. 4, Fig. 1), we thought this feature was related in some way to the particular diagenetic environment. Early cementation with the consequent rapid development of a rigid framework of grains could have feasibly prevented displacive crystallization (Bathurst 1975). Similarly, it might have impeded a replacive origin by adding to the fabric abundant new competitive nuclei for neomorphism. This conjecture, however, turned out to be untenable with the finding of (1) undoubted specimens of S. punctulata with well-developed fringes in other deposits with a similar depositional and early diagenetic history as well as (2) the co-occurrence of rimmed valves of $S$. punctulata and, invariably, nonrimmed spec- 
imens of $S$. astrea in various samples from other Lower Jurassic Tethyan carbonate facies.

\section{DISCUSSION OF DIAGENETIC PROCESSES AND CHRONOLOGY}

Before turning the discussion more specifically to the Hole 547B material, the data presented so far will be reviewed in terms of their potential to indicate diagenetic environment and type of diagenesis. Clearly, the crucial point in intraskeletal cementation of Schizosphaerella is substrate control, inasmuch as the properties of the basic skeletal elements (including morphological, crystallographic, and compositional features) obviously exerted a critical influence on the fabric and, most probably, determined the mineralogical nature of the precipitating phase (e.g., Glover and Pray, 1971). Residual organic matter may have directly assisted in these points (Wilbur and Watabe, 1963) or otherwise influenced the calcite saturation level in the microenvironment to induce local conditions favorable for cement nucleation and growth (e.g., Alexandersson, 1974). Intraskeletal cement thus must not necessarily be representative of the physicochemical parameters of the general diagenetic environment. However, the tendency for Schizosphaerella to accrete abundant secondary overgrowth cement on its skeleton need not be predominantly biochemically induced. Neugebauer (1974) showed that the susceptibility of biogenic calcite crystals to diagenetic overgrowth, and the volume of cement precipitated, depends on crystal size (solubility product) and crystal shape (specific surface energy). In the case of the skeletal elements in question, dimension would not seem to have been an important factor, whereas shape probably was relevant. After decay of the encasing organic matrix when exposed to conditions of inorganic crystal growth, a trend must have originated for the markedly tabular, original skeletal crystallites to approach the thermodynamically stable equilibrium shape (cleavage rhombohedron). This possibly stimulated rapid and vigorous deposition of cement. The growth process obviously ceased upon the mutual interference of crystal boundaries. Orientation of the skeletal crystallites in the test wall did not favor the development of epitaxial extensions far beyond the original skeletal surfaces. This implies that cementation was not normally conductive to grain cohesion (unless schizosphaerellid skeletons were densely packed, constituting a supporting frame), but merely offered (more or less closely spaced throughout the sediment) potential mineralogically stable nucleation sites for further diagenetic carbonate becoming progressively available during subsequent diagenetic evolution. The radially structured calcite crusts usually enveloping the valves in $S$. punctulata are a demonstration of this phenomenon. The reason why there is apparently no analogous structure in $S$. astrea is not clear. Nevertheless, the evidence presented above suggests that the formation of a fringing crust is in some way opposed by the specific surface topography originating with skeletal cementation and not related to any particular diagenetic condition.

On the other hand, thickness of the fringing crusts on S. punctulata, in the fine- and relatively even-grained (mud-supported) lithologies examined from the Tethyan realm, correlates roughly with the overall carbonate content, although there is normally still considerable scatter even over the small surface observed in the SEM. Coarser-grained lithologies (calcarenites, coarse calcisiltites; all current-deposited in our samples), with presumably a grain-supported depositional texture and larger frame interstices, appear not to share this trend. Typical envelopes are only rudimentary (Pl. 3, Figs. 1-3) and sometimes completely missing, with the valves (in a more or less advanced stage of intraskeletal cementation) abutting directly against blocky spar. From such fabric relationships we may infer that, in these cases, development of crusts was not competitive in fabric evolution whatever the exact mechanism involved in their formation. The presence of plenty of coarse grains, many of them monocrystalline, was presumably decisive; these accreted cement more easily or expanded to replace at higher rates than the crusts founded on a polycrystalline substrate of $\mu \mathrm{m}$-sized crystals (competitive cementation, Pray in Bathurst, 1975, or "competitive neomorphism"). In marls, envelopes similarly turned out to be usually absent or blocked in an embryonic stage of development. There, a thin concentric seam of clay flakes, normally found wrapped around the valves, probably impeded crystal growth.

From the examples illustrated in Plates 2 and 3, it appears that the radially structured crusts may overlie valves in quite different stages of intraskeletal cementation; yet, in a given lithology, the degree of alteration of the encrusted valves has proved to be markedly consistent. However, there is invariably a clear discontinuity between the crust and its foundation, whether or not the crust rests on a skeleton having undergone only slight overgrowth (with relic voids beneath the fringing prismatic crystals suggesting that nucleation took place on an persistent organic sheath lining the valve; see Pl. 2, Fig. 4 and above) or whether it overlies a heavily overgrown valve surface (with the syntaxial overgrowth cement overstepping the bounds of the skeletal wall and hence, the cement crystal mosaic most likely reflecting the substratum; e.g., Pl. 3, Fig. 3).

Collectively, these observations suggest that intraskeletal cementation and encrustation are not linked in a simple way and that appearance of the crusts is not locally controlled, but rather correlates with a distinct change in diagenetic conditions affecting the deposit as a whole. Crusts, therefore, should reflect the general characteristics of the diagenetic regime at the instant of their formation better than intraskeletal cement, because of the paramount influence of the substratum on growth in the case of the latter. Nevertheless, in practice, it appears difficult at best to single out this information on the basis of currently available data. Much depends, for example, on an understanding of the exact mechanism of formation of these radially fibrous or bladed fabrics. However, as stated previously, evidence as to the diagenetic process(es) involved is inconclusive. Moreover, presently we do not possess detailed geochemical data that could possibly help in resolving the question of involvement of a metastable precursor or in discriminating between 
the various possibilities. When relying on the morphology of the individual crystallites in the crusts alone, one is tempted to interpret them as having crystallized originally in a Mg-rich marine diagenetic environment (at the seafloor or in the shallow subsurface) as high-magnesian calcite or aragonite (Folk, 1974; Lindholm, 1974) and stabilized later through neomorphism under fabric retention. Such straightforward inference hardly appears warranted in the case in question, inasmuch as we are obviously not dealing with free-growing crystals. Rather, we think that in this case crystals owe their columnar habit largely to simultaneous and regular nucleation and subsequent mutual growth (kinetically controlled "columnar impingement texture", Spry, 1969; Kendall and Broughton, 1977).

There is, in fact, independent evidence that points to, contrary to what might be suggested by crystal morphology, a fairly stable initial mineralogic composition of the fringing crusts on $S$. punctulata and allows, in particular, aragonite to be ruled out as a potential precursor. In many of the facies examined, skeletal material of established aragonitic primary composition, especially ammonite phragmocones or their fragments, constitute a common rock component. The mode of preservation displayed by these shells indicates that aragonite, if allowed to survive into the burial stage, tended to be leached selectively from the sediment by wholesale dissolution, obviously as a consequence of prolonged undersaturation of the pore waters with respect to this polymorph. Depending on the degree of lithification of the embedding mud at the time the aragonite was leached out, either a shell mold filled with blocky spar cement and, in cases, geopetal internal sediment or an inconspicuous suture was created resulting from the compactional collapse of the moldic cavity remains over of the former cephalopod skeleton (compare Schlager, 1974). If originally aragonite, the radially structured fabrics overlying the valves of $S$. punctulata in the matrix would be expected to react accordingly; yet, their morphologic characteristics were found to be identical regardless of the mode of preservation of the original aragonitic shell material.

In order to clarify both the mechanism operating in fringe formation and possible sources for the diagenetic carbonate involved, it would be interesting to time fringe development relative to aragonite leaching. Establishing the critical cross-cutting relations (the method generally applied when confronted with interpreting time sequences from diagenetic textures) is, of course, not easy, especially considering the deci-micron size of the radiating crystals in the crusts. Moreover, processes such as prolonged compactional deformation and pressure solution active during later diagenetic phases are likely to affect textural relationships on this scale. However, on the basis of the following observations, we think that growth of the fringes postdates the main phase of aragonite leaching or that the two processes might run penecontemporaneously, possibly one aiding the other: (1) In cases where there is a sharp contact preserved between the encasing host sediment and a successive generation of lime mud filtered into the moldic cavity left by a dissolved aragonitic shell, the radially structured fabrics enveloping schizosphaerellids located on either side typically cross this limit. The same appears to occur along the boundary between host and phragmocone-filling sediment in the case of collapsed molds, but evidence there is often inconclusive. Such contacts tend to be less distinct or there is an intervening zone of concentrated insoluble residues. (2) Again, in the case of preserved, undeformed skeletal molds (with aragonite dissolution having obviously occurred within a firm sediment), schizosphaerellids are found occasionally with part of the overlying fringing prismatic crystals merging distally in the finely crystalline initial cement mosaic lining the spar-filled moldic cavity.

In view of the earlier development in the sediment of an unyielding framework of grains in some cases, the chance for expansive crystal growth to represent the determinant mechanism in fringe formation would seem to be reduced. However, we can not be sure whether this applies throughout, or whether in the case of delayed consolidation and selective leaching of chemically unstable carbonate phases in the shallow subsurface (under more stagnant conditions), pore fluids could concentrate to the critical supersaturation necessary for displacive crystallization to occur (Watts, 1978; Neugebauer, 1979). After all, we feel that the fabric in question is probably best interpreted as a product of aggrading (porphyroid) neomorphism (Bathurst, 1975) associated with mineralogic stabilization of the initial, presumably polyphase, disequilibrium sedimentary assemblage. In this view, initiation of development of the fringing crusts might correlate, in the diagenetic evolution of a given sediment, with the onset of neomorphism and growth of the fabric might coincide with the main phase of elimination of primary metastable carbonate phases surviving into the burial stage. Moreover, in absence of other, more competitive nuclei for neomorphism, $S$. punctula$t a$, if present in significant numbers, is likely to become rate determining in this process of stabilization and therefore of critical influence on the evolution of the diagenetic potential of the sediment as a whole. A number of fabric relationships (see Pls. 8-12) yield strong presumptive evidence that the growth of the radially structured crusts on $S$. punctulata took place and essential mineralogic stabilization occurred relatively early in the diagenetic history (similar to fresh water diagenesis; e.g., Land, 1967; Steinen, 1978; Longman, 1980). The sediment, therefore, entered deeper burial realms probably as a mineralogically stable assemblage and successive diagenetic alteration presumably proceeded at a much slower rate. As in burial diagenesis of predominantly calcitic pelagic oozes, further reduction of the remaining porosity and the eventual conversion into a tight micritic limestone might then be achieved largely by pressure solution and reprecipitation (chemical compaction) with increasing overburden (Neugebauer, 1974; Schlanger and Douglas, 1974; Hudson, 1975). 


\section{RESULTS FROM HOLE 547B AND GENERAL IMPLICATIONS FOR THE DIAGENESIS OF EARLY MESOZOIC DEEPER-MARINE CARBONATES}

Extensive aggrading neomorphism is generally thought to be tied up with low-Mg diagenetic environments, because of the inhibitory effect of an elevated $\mathrm{Mg}^{2+}$ concentration in interstitial fluids on the growth of calcite (Folk, 1974; Lahann, 1978). The onset of neomorphism thus would seem to become delayed in burial diagenesis under the seafloor to an advanced stage of diagenesis at greater sub-bottom depths (after depletion of formation waters in $\mathrm{Mg}^{2+}$ due to "capture" by clays or dolomite [Folk, 1974] or consumption with nucleation of opalCT during silica diagenesis [Kastner et al., 1977]), unless an eustatic fall of sea level or tectonic uplift caused fresh or brackish water to come into contact with the sediment at some earlier time. No conclusive data are, however, available regarding the effective depth range at which aggrading neomorphism first becomes an important process in marine burial diagenesis. This is clearly related to the fact that detailed work on progressive lithification in continuous carbonate sequences (summary in Scholle, 1977) recovered from under the ocean floors has thus far centered on post-Jurassic pelagic nannofossil deposits. These deposits typically have a stable initial low-Mg calcite composition, and chemical compaction is the paramount hardening mechanism. From Folk's (1974) account we may deduce that neomorphism is unlikely to become efficient in a buried marine sediment before the $\mathrm{Mg} / \mathrm{Ca}$ concentration ratio in the pore fluid is reduced from the initial value of sea water to a value of about 2, and probably even well below. A corresponding figure (i.e., $\mathrm{Mg} / \mathrm{Ca}$ ratio of 2 to 1 , or an absolute concentration of about $0.01 \mathrm{M} \mathrm{Mg}$ ) arises from Neugebauer's $(1973 ; 1974)$ studies as the minimum magnesium content required for the inhibition of hardening in chalks. On the basis of pore fluid data from numerous deep sea drilling sites, the same author concluded that magnesium concentration in interstitial waters of deep sea chalks normally drops into the critical range at approximately $1000-1600 \mathrm{~m}$ sub-bottom depth. Only beyond this burial depth does production of cement by pressure solution become significant, resulting finally in a virtually thorough lithification under $2-4 \mathrm{~km}$ overload. Limited quantities of cement may, however, be generated by this process even in low-Mg calcite sediments at much shallower burial depths. In the case of particularly small interparticle contact areas, the necessary compensation stress allowing pressure solution to occur may build up with relatively little overburden. As expected, the picture changes substantially when an initial multiphase carbonate assemblage is considered. Neugebauer's model for the diagenesis of chalk predicts that notable admixtures of aragonite and high-Mg calcite should significantly affect the rate of burial-related loss of porosity and of lithification: Magnesium induces $\mathrm{Ca}^{2+}$ and $\mathrm{CO}_{3}^{2+}$ ionic concentrations in the pore fluid to rise to a figure in the range of the solubility product of aragonite or high- $\mathrm{Mg}$ calcite (with $10-20 \mathrm{~mol} \% \mathrm{Mg}$ ).
Thus, no relevant threshold linear pressure need be overcome for pressure solution to initiate along contacts with such grains. We may therefore infer that, under normal conditions of burial, chemically unstable components in a carbonate deposit are obliterated by way of pressure solution, unless stabilized in a fairly early stage of burial.

At Hole 547B, Jurassic sediments were encountered at a sub-bottom depth of about $775 \mathrm{~m}$ and crossed over an interval of approximately $150 \mathrm{~m}$. The tectonic setting and the interpreted geologic history of the area (see site report, this volume) suggest that overburden at this site is unlikely ever to have exceeded the actual value, and that moreover, from the Early Jurassic onwards, depositional and burial history were most probably continuously marine. This is in obvious contrast to the Tethyan counterparts on land that were, after deposition, exposed to tectonic stresses and uplift during and after Alpine orogenesis and eventually were exposed to fresh water. Therefore, the textures preserved in the Jurassic deposits drilled at Hole 547B and, in particular, the mode of preservation of the included schizosphaerellids should provide important clues relevant to the above discussion. Scanning electron micrographs illustrating ultrastructural details and preservational characteristics of $S$. punctulata and $S$. astrea from Cores 547B-11 through 547B-23 are shown in Plates 5 and 6 . In addition, combined overview SEM and light-micrographs from four representative lithologic types out of the Jurassic succession at Hole 547B are shown in Plate 7 in order to illustrate the more general microtexture. As regards the preservation of schizosphaerellids, SEM revealed in the subsea samples a considerable variety of diagenetic morphotypes, all fitting into the pattern of progressive alteration described previously. Fossilized more or less advanced stages of intraskeletal cementation prevail. However, in a number of samples, covering the interval from Core 547B-15 to 547B-23, preserved initial stages of a fringing crust are commonly recognized on specimens of S. punctulata (Pl. 5, Figs. 2, 3) and occasionally even well-developed fabrics of radially arranged bladed calcite occur (PI. 5, Fig. 5). Thus, the prevalence of specimens altered to a moderate degree does not conflict with the above inferences concerning both time and mechanism of alteration. As already apparent from Tethyan examples, there must be a great many factors (including clay and organic content of the host sediment, depositional texture, and probably many more) that influence the mode of final preservation of Schizosphaerella in a given sediment type. In Hole 547B, such complex control is also suggested by a clearly nonsystematic variation of the degree of diagenetic alteration downhole.

A comparison between the overall diagenetic pattern revealed by the samples from Hole 547B and by the sediments of equal age examined from numerous Tethyan localities generally supports the impression which has repeatedly emerged from similar studies (Bernoulli, 1972), i.e., undersea material has a lesser diagenetic "maturity" than material collected in mountain belts. However, a closer comparison shows that most of the Upper Jurassic-Cretaceous or younger, deeper- and deep-ma- 
rine, largely low-Mg calcite sediments exhibit a marked contrast to Tethyan sediments of comparable age. In contrast, textural differences between the pre-Upper Jurassic sediments at Hole 547B and Tethyan lithologies of similar age on land appear subtle. It is often only a perceptibly lesser degree of hardening, rather than their (micro)fabric (such as visible porosity, etc.) that distinguishes the core samples. Similarly, a markedly tighter fabric and, inferentially, a more extensive postdepositional alteration is recognized in micrographs of the Hole 547B Jurassic carbonate facies when compared with other pelagic carbonate sediments generally of postJurassic age, recovered by deep sea drilling from corresponding or even greater sub-bottom depths. The greater age must certainly influence this alteration, but is probably not the crucial factor. Rather, we think this stronger degree of lithification is related to a more varied primary mineralogical composition of these sediments, especially when compared to pelagic carbonate oozes formed after the evolutionary bloom of low-Mg calcite plankton by the close of the Jurassic period. As discussed by Sandberg (1975), this same major paleoceanographic event must have entailed a relative $\mathrm{Mg}$ increase in seawater (see also Broecker, 1974; Folk, 1974); thus, a lower $\mathrm{Mg} / \mathrm{Ca}$ concentration ratio in the pre-Late Jurassic oceanic system and in marine pore fluids must also be considered. Such a change must affect the evolution of the diagenetic potential. Especially in the case of a highly reactive mixed initial carbonate assemblage, we may logically presume an enhanced rate of diagenesis in the shallow burial realm, inasmuch as a lower relative $\mathrm{Mg}^{2+}$ concentration in interstitial waters would have caused stabilizing reactions (under present conditions retarded by high oceanic $\mathrm{Mg} / \mathrm{Ca}$ activity ratios) to occur earlier in the burial history. We may then further speculate that such a shift would have favored the operation of additional mechanisms besides the (largely burial dependent) mechanical and chemical compaction that dominates in burial diagenesis. In particular, it might have allowed neomorphism to significantly influence the textural evolution of a sediment and the fabric presently observed. Based on evidence from land and from under the sea evidence, we can begin to decipher the complex process of lithification of the deeper-marine carbonate facies that occur widely along early Mesozoic continental margin. The pattern that develops appears to have affinities to fresh water phreatic diagenesis rather than with present undersea burial diagenesis. Because stabilization normally occurred at relatively shallow burial depths, deep and post-burial effects took on minor importance.

\section{ACKNOWLEDGMENTS}

We are grateful to the Deep Sea Drilling Project and particularly to E. L. Winterer for the opportunity to study core samples from Site 547. Financial support for this study came from the Swiss National Science Foundation (Grant 2.650-0.80). R. Guggenheim provided facilities at the SEM Laboratory at the Geologisches Institut der Universität Basel; S. Bowald and T. Catin operated the SEM and prepared the photomicrographs. We thank P. O. Baumgartner, S. Graeser, B. C. Schreiber, A. Spinnler, and L. Strasser for their help. H. C. Jenkyns, R. M. Leckie, A. Matter, K. Perch-Nielsen, and H. Weissert reviewed the manuscript.

\section{REFERENCES}

Alexandersson, T., 1974. Carbonate cementation in coralline algal nodules in the Skagerak, North Sea: biochemical precipitation in undersaturated waters. J. Sediment. Petrol., 44:7-26.

Amezieux, J., 1972. Association de nannofossils calcaires du Jurassique d'Aquitaine et du Bassin Parisien (France). Mem. Bur. Rech. Geol. Min., 77:143-151.

Aubry, M.-P., Bignot, G., Bismuth, H., and Remane, J., 1975. Premiers résultats de l'observation au MEB de la lorica des calpionelles et de quelques microfossiles qui leur sont associés. Rev. Micropaleont., 18:127-133.

Aubry, M.-P., and Dépêche, F., 1974. Recherches sur les schizosphères. Cah. Micropaleont., 1:1-13

Bathurst, R. C. G., 1975. Carbonate Sediments and their Diagenesis: Amsterdam (Elsevier).

Baumgartner, P. O., De Wever, P., and Kocher, R., 1980. Correlation of Tethyan Late Jurassic-Early Cretaceous radiolarian events. Cah. Micropaleont., 2:23-85.

Bernoulli, D., 1972. North Atlantic and Mediterranean Mesozoic facies: a comparison. In Hollister, D. C., Ewing, J. I., et al. Init. Repts. DSDP, 11: Washington (U.S. Govt. Printing Office), 801-871.

Bernoulli, D., and Jenkyns, H. C., 1970. A Jurassic Basin: The Glasenbach Gorge, Salzburg, Austria. Verh. Geol. Bundesanst. (Wien): 504-531.

Bernoulli, D., and Renz, O., 1970. Jurassic carbonate facies and new ammonite faunas from Western Greece. Eclogae Geol. Helv., 63: 573-607.

Black, M., 1971. Problematical microfossils from the Gault Clay. Geol. Mag., 108:325-327.

Bolli, H. M., 1974. Jurassic and Cretaceous Calcisphaerulidae from DSDP Leg 27, Eastern Indian Ocean. In Veevers, J. J., Heirtzler, J. R., et al., Init. Repts. DSDP, 27: Washington (U.S. Govt. Printing Office), 843-907.

Broecker, W. S., 1974. Chemical Oceanography: New York (Harcourt Brace Jovanovich, Inc.).

Burckle, L. H., 1979. Diatoms. In Fairbridge, R. W., and Jablonski, D. (Eds.), The Encyclopedia of Paleontology. Encycl. Earth Sci., VII: Stroudsburg, PA (Dowden, Hutchinson and Ross, Inc.), 247-253.

Dangeard, L., 1942. Schizosphères et organismes en clochette du Jurassique. Bull. Soc. Linn. Normandie, 9(2):10-11.

Deflandre, G., 1954. Observations sur les Coccolithophoridae actuels et fossiles en microscope optique et électronique. Ann. Paleont., 40:115-176.

Deflandre, G., and Dangeard, L., 1938. Schizosphaerella, un nouveau microfossile méconnu du Jurassique moyen et supérieur. C.R. Acad. Sci. (Paris), 207:1115-1117.

Folk, R. L., 1965. Some aspects of recrystallization in ancient limestones. In Pray, L. C., and Murray, R. C. (Eds.), Dolomitization and Limestone Diagenesis: a Symposium. Soc. Econ. Paleontol. Mineral Spec. Publ., 13:14-48.

1974. The natural history of crystalline calcium carbonate: effect of magnesium content and salinity. J. Sediment. Petrol., 44: 40-53.

Fütterer, D., 1976. Kalkige Dinoflagellaten ("Calciodinelloidae”) und die systematische Stellung der Thoracosphaeroideae. $N$. Jb. Geol. Palaont. (Abh.), 151:119-141.

1977. Distribution of calcareous dinoflagellates in Cenozoic sediments of Site 366, eastern North Atlantic. In Lancelot, Y., Seibold, E., et al. Init. Repts. DSDP, 41: Washington (U.S. Govt. Printing Office), 709-738.

Glover, E. D., and Pray, L. C., 1971. High-magnesian calcite and aragonite cementation within modern subtidal carbonate sediment grains. In Bricker, O. P. (Ed.), Carbonate Cements: Baltimore (Johns Hopkins Press), 80-87.

Hudson, J. D., 1975. Carbon isotopes and limestone cement. Geology, 3:19-22.

Jafar, S. A., 1979. Taxonomy, stratigraphy and affinities of calcareous nannoplankton genus Thoracosphaera Kamptner. In Bharadwaj, D. C., Singh, H. P., and Tiwari, R. S. (Eds.), Proc. IV Int. Palynol. Congr., Lucknow (India), 2:1-21.

James, N. P., and Ginsburg, R. N., 1979. The Seaward Margin of Belize Barrier and Atoll Reefs. Spec. Publ. Int. Assoc. Sedimentol., 3. 
Kälin, O., 1980. Schizosphaerella punctulata Deflandre \& Dangeard: Wall ultrastructure and preservation in deeper-water carbonate sediments of the Tethyan Jurassic. Eclogae Geol. Helv., 73:983-1008.

Kälin, O., Patacca, E., and Renz, O., 1979. Jurassic pelagic deposits from Southeastern Tuscany; aspects of sedimentation and new biostratigraphic data. Eclogae Geol. Helv., 72:715-762.

Kamptner, E., 1927. Beitrag zur Kenntnis adriatischer Coccolithophoriden. Arch. Protistenk., 58:173-184.

Kastner, M., Keene, J. B., and Gieskes, J. M., 1977. Diagenesis of siliceous oozes-I. Chemical controls on the rate of opal-A to opalCT transformation-an experimental study. Geochim. Cosmochim. Acta, 41:1041-1059.

Kendall, A. C., and Broughton, P. L., 1977. Discussion: calcite and aragonite fabrics, Carlsbad Caverns: by R. L. Folk and R. Assereto, J. Sediment. Petrol., 46:486-496. J. Sediment. Petrol., 47: $1397-1400$.

Kendall, A. C., and Broughton, P. L., 1978. Origin of fabrics in speleothems composed of columnar calcite crystals. J. Sediment. Petrol., 48:519-538.

Kendall, A. C., and Tucker, M. E., 1973. Radiaxial fibrous calcite: a replacement after acicular carbonate. Sedimentol., 20:365-389.

Keupp, H., 1979. Lower Cretaceous Calcisphaerulidae and their relationship to calcareous dinoflagellate cysts. Bull. Cent. Rech. Explor--Prod. Elf-Aquitaine, 3:651-663.

1980. Pithonella patriciagreeleyae Bolli 1974, eine kalkige Dinoflagellaten-Zyste mit interner Paratabulation (Unter-Kreide, Speeton/SE-England). N. Jb. Geol. Palaont. (Mh.), 9:513-524.

Kocher, R., 1981. Biostratigraphische Untersuchungen oberjurassischer radiolarienführender Gesteine, insbesondere Südalpen. Mitt. Geol. Inst. Eth u. Univ. Zurich, N.F. 234:1-184.

Lahann, R. W., 1978. A chemical model for calcite crystal growth and morphology control. J. Sediment. Petrol., 48:337-344.

Land, L. S., 1967. Diagenesis of skeletal carbonates. J. Sediment. Petrol., 37:914-930.

Lezaud, L., 1967. Nannofossiles calcaires du Jurassique supérieur de la Baie de Seine. Bull. Soc. Geol. Normandie, 57:15-20.

Lindholm, R. C., 1974. Fabric and chemistry of pore filling calcite in septarian veins: Models for limestone cementation. J. Sediment. petrol., 44:428-440.

Lohmann, H., 1920. Die Bevölkerung des Ozeans mit Plankton nach den Ergebnissen der Zentrifugenfänge während der Ausreise der "Deutschland" 1911, zugleich ein Beitrag zur Biologie des Atlantischen Ozeans. Arch. Biont., 4:1-617.

Longman, M.W., 1980. Carbonate diagenetic textures from nearsurface diagenetic environments. Amer. Assoc. Petroleum Geol. Bull., 64:461-487.

Lorenz, T., 1901. Geologische Studien im Grenzgebiet zwischen helvetischer und ostalpiner Fazies. Ber. Natf. Ges. Freiburg i. Br., 12: 34-95.

Masters, B. A., and Scott, R. W., 1978. Microstructure, affinities and systematics of Cretaceous calcispheres. Micropaleontol., 24: 210-221.

Mazzullo, S. J., 1980. Calcite pseudospar replacive of marine acicular aragonite, and implications for aragonite cement diagenesis. J. Sediment. Petrol., 50:409-422.

Medd, A. W., 1979. The Upper Jurassic coccoliths from the Haddenham and Gramlingay boreholes (Cambridgeshire, England). Eclogae Geol. Helv.,72:19-109.

, 1982. Nannofossil zonation of the English Middle and Upper Jurassic. Marine Micropaleontol., 7:73-95.

Moshkovitz, S., 1979. On the distribution of Schizosphaerella punctulata Deflandre \& Dangeard and Schizosphaerella astrea n.sp. in the Liassic section of Stowell Park Borehole (Gloucestershire) and in some other Jurassic localities in England. Eclogae Geol. Helv., $72: 455-465$.
Neugebauer, J., 1973. The diagenetic problem of chalk. The role of pressure solution and pore fluid. N. Jb. Geol. Palaont. (Abh.), 143:223-245.

1974. Some aspects of cementation in chalk. In Hsü, K. J., and Jenkyns, H. C. (Eds.), Pelagic Sediments: on Land and under the Sea. Spec. Publ. Int. Assoc. Sedimentol., 1:149-176. 1979. Fossil-Diagenese in der Schreibkreide Echinodermen. Clausth. Geol. Abh., 30:198-229.

Pautard, F. G. E., 1970. Calcification in unicellular organisms. In Schraer, H. (Ed.), Biological Calcification: cellular and molecular Aspects: Amsterdam (Elsevier/North Holland Publishing Company), 105-201.

Riech, V., and von Rad, U., 1979. Silica diagenesis in the Atlantic Ocean: diagenetic potential and transformations. In Talwani, M., Hay, W., and Ryan, W. B. F. (Eds.), Deep Drilling Results in the Atlantic Ocean: Continental Margins and Paleoenvironment. Amer. Geophys. Un., Maurice Ewing Ser. 3: 315-340.

Sandberg, P. A., 1975. New interpretations of Great Salt Lake ooids and of ancient non-skeletal carbonate mineralogy. Sedimentol., 22:497-537.

Schlager, W., 1974. Preservation of cephalopod skeletons and carbonate dissolution on ancient Tethyan sea floors. In Hsü, K. J., and Jenkyns, H. C. (Eds.), Pelagic Sediments: on Land and under the Sea. Spec. Publ. Int. Assoc. Sedimentol., 1:49-70.

Schlager, W., and James, N. P., 1978. Low-magnesium calcite limestones forming at the deep-sea floor, Tongue of the Ocean, Bahamas. Sedimentol., 25:675-702.

Schlanger, S. O., and Douglas, R. G., 1974. The pelagic ooze-chalklimestone transition and its implication for marine stratigraphy. In Hsü, K. J., and Jenkyns, H. C. (Eds.), Pelagic Sediments: on Land and under the Sea. Spec. Publ. Int. Assoc. Sedimentol., 1:117-148.

Scholle, P. A., 1977. Chalk diagenesis and its relation to petroleum exploration: Oil from chalks, a modern miracle? Amer. Assoc. Petroleum Geol. Bull., 61:982-1009.

Schroeder, J. H., 1972a. Fabrics and sequences of submarine carbonate cements in Holocene Bermuda cup reefs. Geol. Rdsch., 61: 708-730.

1972b. Calcified filaments of an endolithic alga in Recent Bermuda reefs. N. Jb. Geol. Palaont. (Mh.), 1:16-33.

Spry, A., 1969. Metamorphic Textures: Oxford (Pergamon Press).

Steinen, R. P., 1978. On the diagenesis of lime mud: scanning electron microscopic observations of subsurface material from Barbados, W.I. J. Sediment. Petrol., 48:1139-1148.

Tangen, K., Brand, L. E., Blackwelder, P. L., and Guillard, R. R. L., 1982. Thoracosphaera heimii (Lohmann) Kamptner is a dinophyte: observations on its morphology and life cycle. Marine Micropaleontol., 7:193-212.

Villain, J.-M., 1975. "Calcisphaerulidae" (Incertae sedis) du Crétacé supérieur du Limbourg (Pays-Bas), et d'autres régions. Palaeontographica, 149:193-242.

1977. Les Calcisphaerulidae: Architectures, calcification de la paroi et phylogénèse. Palaeontographica, 159:139-177.

Wanner, J., 1940. Gesteinsbildende Foraminiferen Malm und Unterkreide des östlichen Ostindischen Archipels. Pal. Z. 22:75-99.

Watts, N. L., 1978. Displacive calcite: Evidence from recent and ancient calcretes. Geology, 6:699-703.

Wilbur, K. M., and Watabe, N., 1963. Experimental studies on calcification in molluscs and the alga Coccolithus huxleyi. Ann. New York Acad. Sci., 109:82-112.

Date of Initial Receipt: July 29, 1983

Date of Acceptance: August 4, 1983 

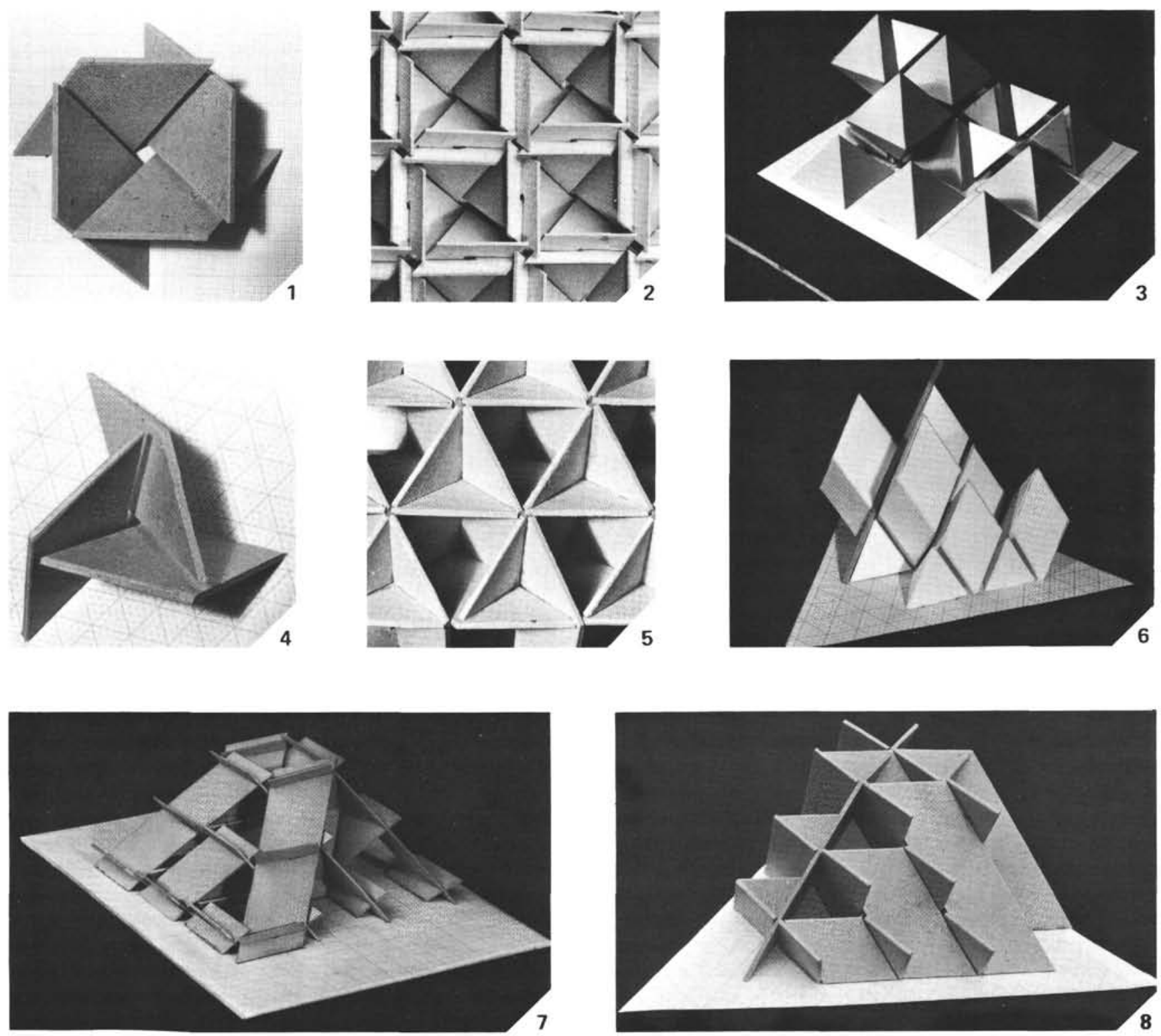

Plate 1. Wall ultrastructure of Schizosphaerella punctulata and Schizosphaerella astrea, carton models. In order to facilitate construction the presumed rhombohedral symmetry of the fundamental structural elements (see text) has been disregarded in all models; simple parallelogramshaped carton lamellae have been used instead, with the edges including $60^{\circ}$ and $120^{\circ}$ angles, respectively. These values have been chosen for simplicification as the validity of the proposed structural models is not restricted to any specific angle. In the case of the models for the $S$. astrea test wall ultrastructure, the presumed original interspaces between adjacent lamellae were not considered: 1 . Basic tetragonal arrangement of the fundamental structural elements in S. punctulata. 2. Ultrastructural pattern of valve surface in S. punctulata. 3. Spatial arrangement of the square-bipyramidal and sphenoidal voids occurring in the test wall of $S$. punctulata. 4. Basic triangulate arrangement of the fundamental structural elements in $S$. astrea. 5. Ultrastructural pattern of valve surface in $S$. astrea. 6. Spatial arrangement of the rhombohedron-shaped voids occurring in the test wall of $S$. astrea. 7. Wall ultrastructure of $S$. punctulata. 8. Inferred fundamental wall ultrastructure of $S$. astrea. By systematically varying the length of part of the elementary lamellae in the constructional models in Figs. 7 and 8 , we are able to demonstrate the regular recurrence of the square or triangular reticulate pattern (Figs. 2, 5). Valves of different overall thickness may thus reveal identical surface morphology. 


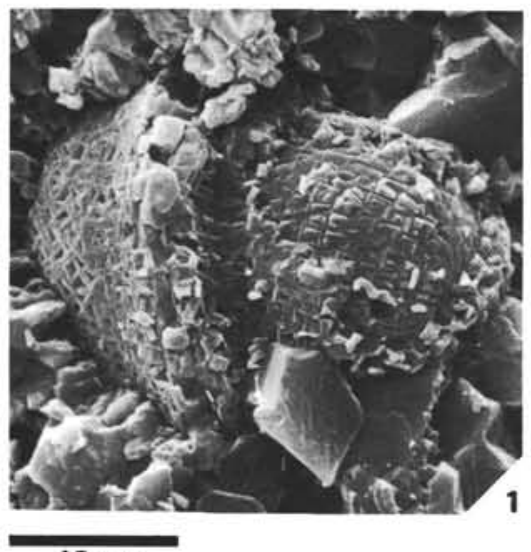

$10 \mu \mathrm{m}$

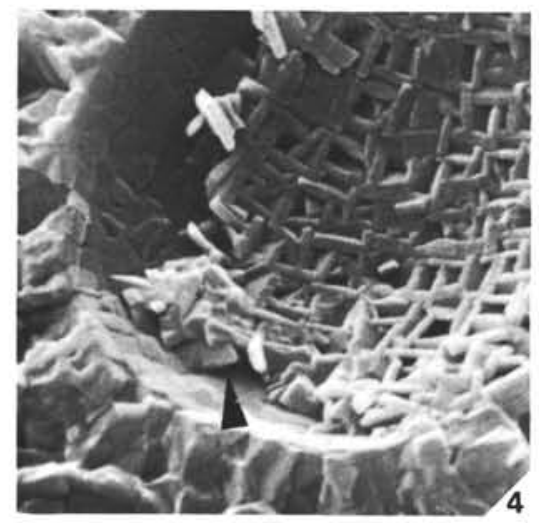

$1 \mu \mathrm{m}$

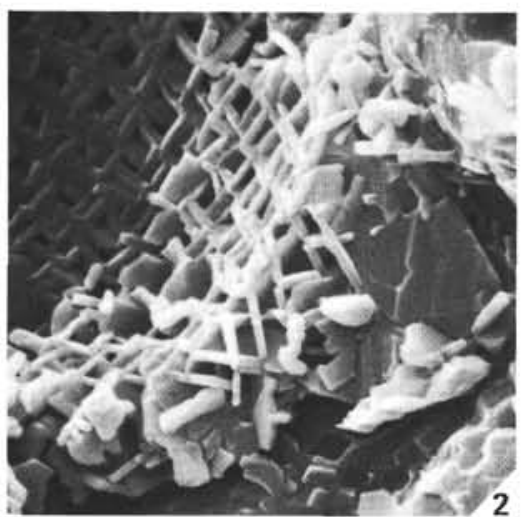

$\overline{1 \mu \mathrm{m}}$

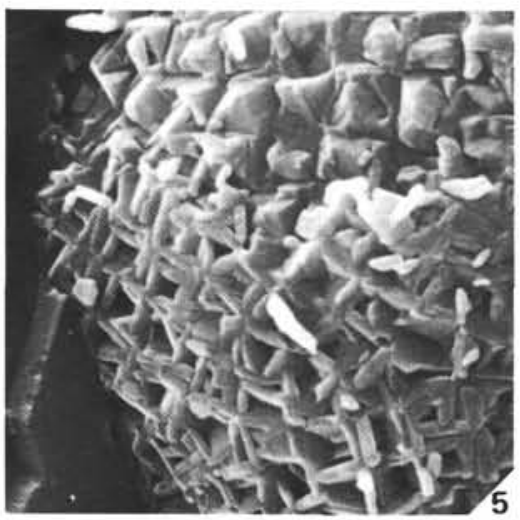

$1 \mu \mathrm{m}$

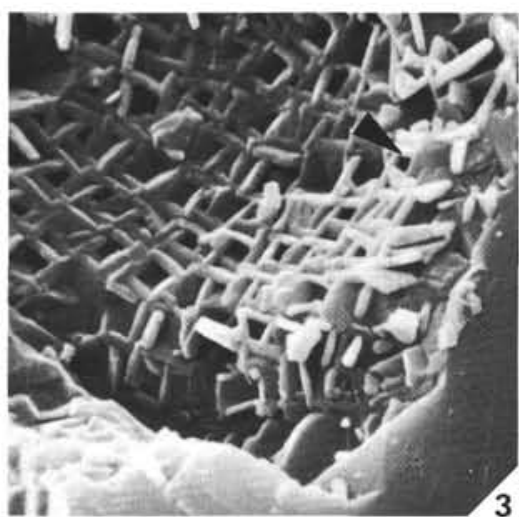

$1 \mu \mathrm{m}$

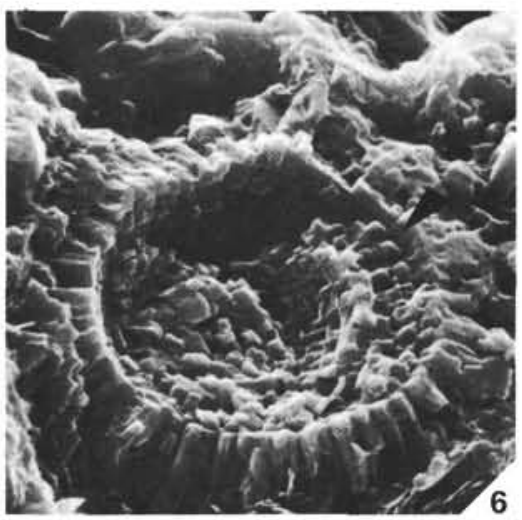

$5 \mu \mathrm{m}$

Plate 2. Schizosphaerella punctulata; test morphology, wall ultrastructure, and its modification with progressive diagenetic overgrowth. SE micrographs of fresh broken rock surfaces. Figs. 1-5 all from Schistes Carton, lower Toarcian, Tournemire, Aveyron, southern France. 1. Thin walled, double valved specimen with bell-shaped hypovalve (left) and cup-shaped epivalve (right). Part of the epivalve is broken away. Exposed proximal terminations of cement crystals founded on the inner valve surface perfectly replicate the skeletal surface structure. 2. Fractured valve revealing the internal structure of the test wall with systematically intergrown lamellar calcite crystallites oriented obliquely to the valve surface. 3, 4, 5. Morphology of inner and outer valve surfaces. The elementary, paralellogram-shaped (arrows in Figs. 3, 4) calcite lamellae are presumably somewhat enlarged by syntaxial overgrowth. The inferred original interspaces between them (see models, Pl. 1) thereby became largely fastened and the primary skeletal structure converted into a more or less tight-fitting frame. In the upper part of Fig. 5, calcite lamellae are largely broken off and a number of cement-filled original square-bipyramidal skeletal voids, arranged in a regular way, are exposed (compare Pl. 3 , Fig. 3). In the valve shown in Fig. 4, intraskeletal cementation was obviously not completed when development of a fringe of radially orientated calcite prisms initiated. Plane bases of the prisms suggest growth on a smooth substratum which most likely was a peripheral organic membrane, still preserved when the fringe started to develop. 6. Fractured valve specimen in an advanced stage of diagenetic alteration. Intraskeletal voids are largely occluded by overgrowth cement (arrow indicates calcite cemented, former bipyramidal, internal skeletal voids) and a thin rim of radiating calcite prisms, with squarish cross sections in their proximal parts, encrusts the valve (see also Fig. 4). Valmaggiore Formation, uppermost Liassic, approx. $1 \mathrm{~km}$ NE of Cittiglio, Lombardian Zone, southern Alps, northern Italy). 

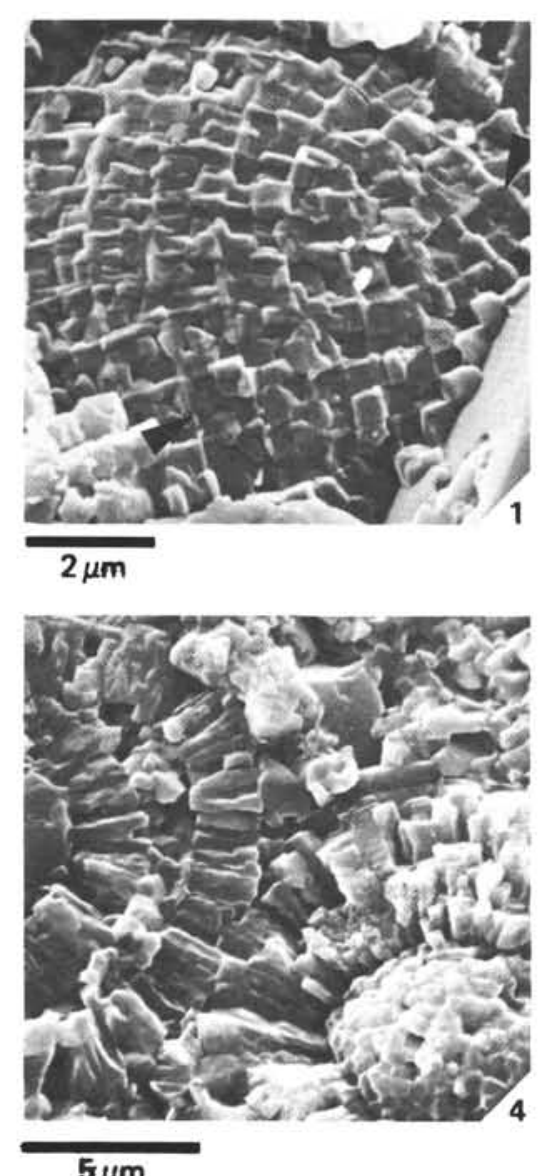

$5 \mu \mathrm{m}$

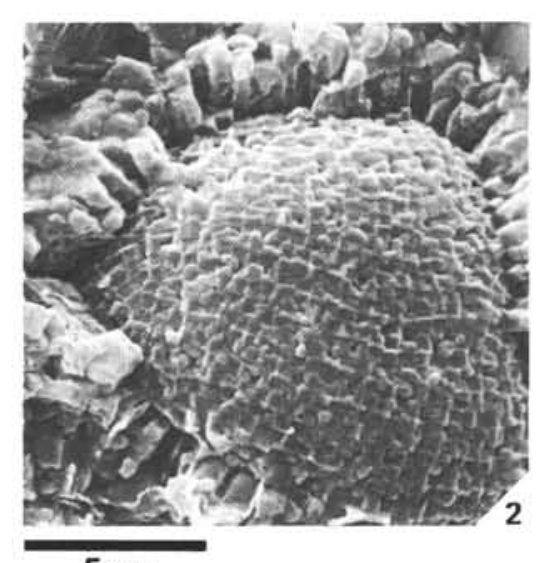

$5 \mu \mathrm{m}$

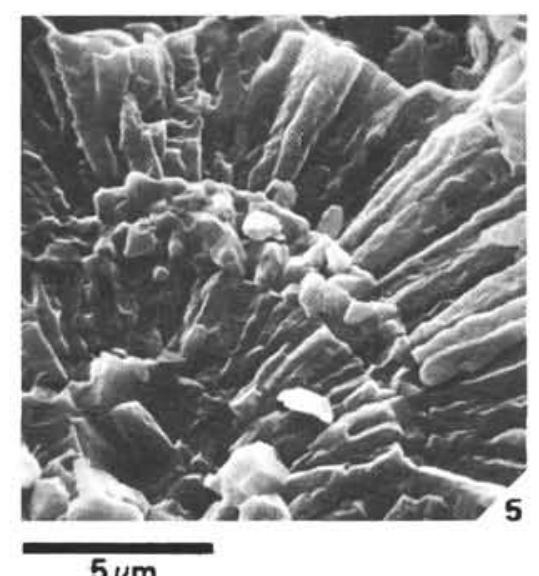

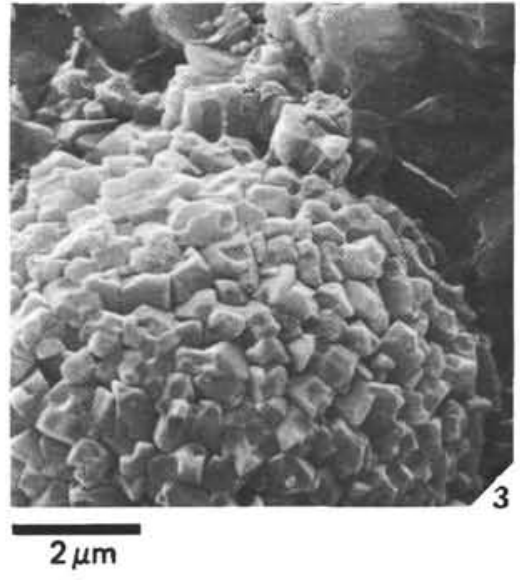

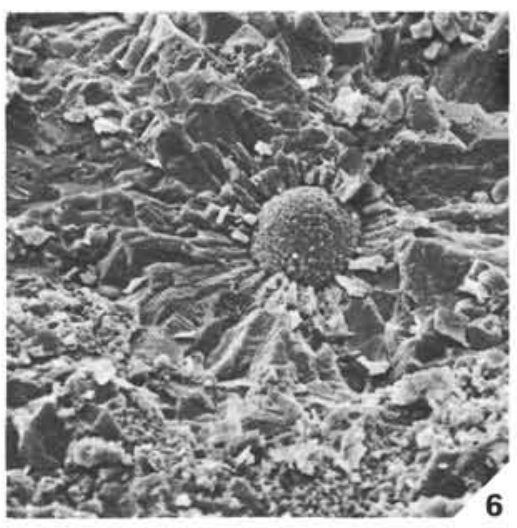

$10 \mu \mathrm{m}$

Plate 3. Schizosphaerella punctulata; diagenetic morphotypes. SE micrographs of fresh broken rock surfaces. 1-2. Surface aspect of diagenetically altered valves. Though the original surface topography is largely smoothed due to precipitation of syntaxial overgrowth cement, the characteristic square-reticulate partition can still be distinguished. Occlusion of individual square-pyramidal primary cavities is accomplished by competitive growth of cement inward from each of the delimiting four lamellar crystallites. Depending on whether or not overgrowth initiated simultaneously and proceeded at identical rates, a more or less symmetrical fabric may arise (see arrows in Fig. 1). Valmaggiore Formation, uppermost Liassic, approx. $1 \mathrm{~km}$ NE of Cittiglio. Lombardian Zone, southern Alps, northern Italy. 3. Diagenetically strongly altered valve surface. Complete obliteration of the primary surface morphology and the development of a random crystal mosaic are the consequence of continued growth of cement, beyond the bounds of the original skeletal frame. Once freed from the controlling influence of the skeletal structure, competition in growth is no more restricted to the crystals involved in the filling of an individual cavity, but favored crystals start to encroach upon others rooted on the sides of adjacent cavities. Marne del Serrone, Toarcian, Valdorbia, Umbrian Apennines, central Italy. 4. Fully cemented valves (subaxially fractured specimen on left) separated by an isopachous fringe of radially arranged, square-ended calcite prisms from surrounding micrite and microspar. Calcare Selcifero, upper Pliensbachian, Monte Cetona, southeastern Tuscany, central Italy. 5. Cross section of fully cemented valve overlain by well-developed crusts of radiating calcite prisms. Sharp and plane proximal terminations of prisms suggest that there is no lattice continuity with their foundation. Distal ends are also predominantly square and they probably represent fossilized growth surfaces, rather than basal pinacoid (crystal) faces. The sides of the prisms show a characteristic crenulate surface texture, markedly contrasting with the largely plane crystal surfaces in the surrounding micrite visible in the lower left corner of the micrograph. As for the origin of the fringing crust, evidence is inconclusive; neomorphic replacement and/or displacive precipitation are possibly involved. Calcare Selcifero, upper Pliensbachian, Monte Cetona, southeastern Tuscany, central Italy. 6. Fringed valve forming the core of a stellate aggregate of (?)neomorphic (micro)spar. Peripheral coarse crystals grow in continuity with prismatic crystals encrusting the valve surface. At some distance from the valve (presumably at the outer surface of the initial fringing crust), a marked reduction in the number (and a rather abrupt increase in size/thickness) of crystals in the fabric occurs, implying that many of the basal prisms became crowded out (?or coalesced) with the development of the stellate fabric. Medolo Formation, upper Pliensbachian, Botticino, Lombardian Zone, southern Alps, northern Italy. 


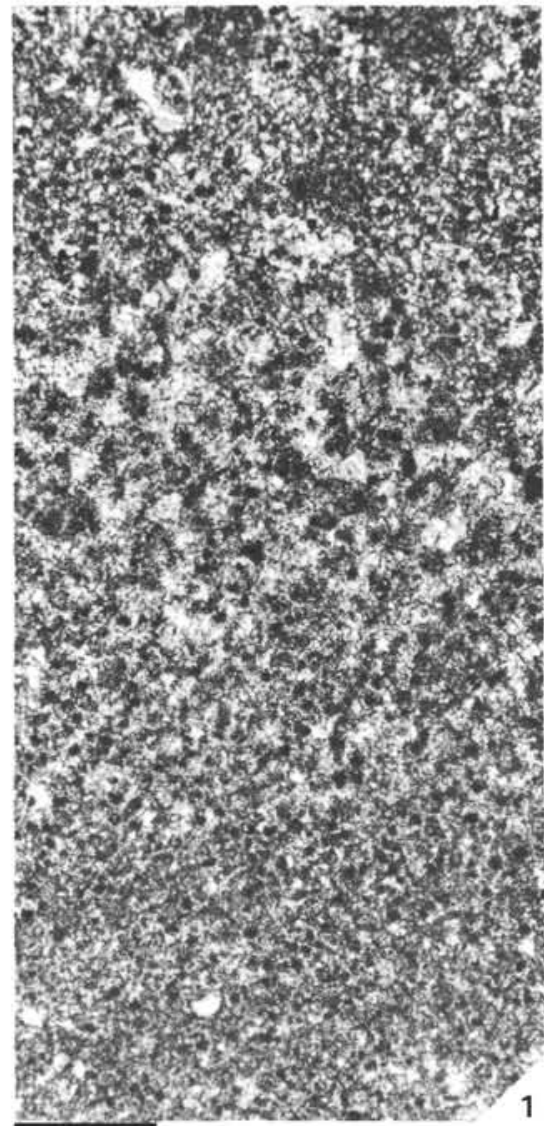

$250 \mu \mathrm{m}$

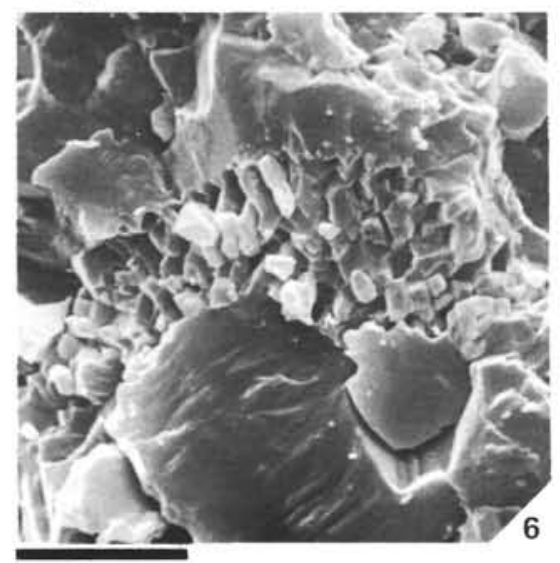

$5 \mu \mathrm{m}$

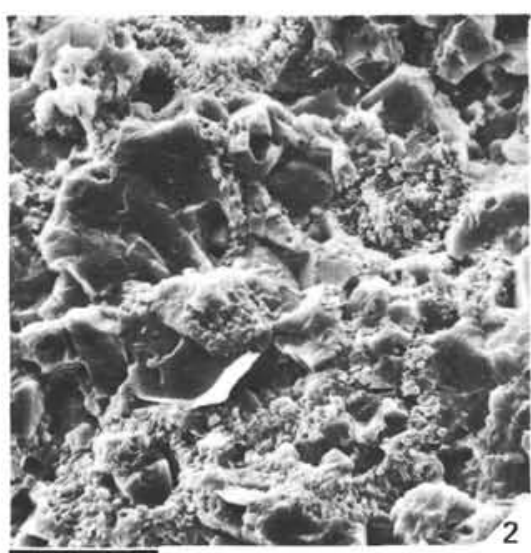

$20 \mu \mathrm{m}$

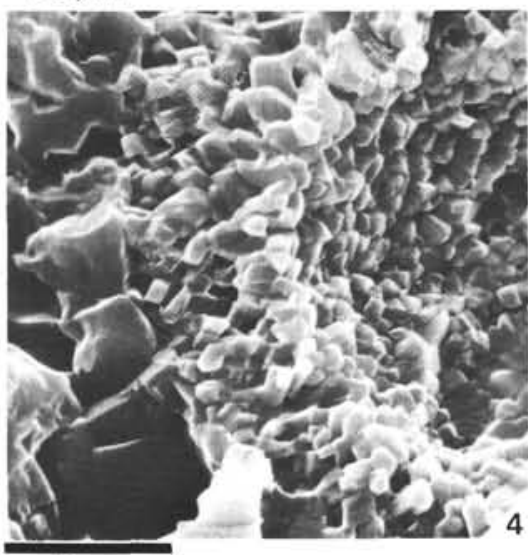

$5 \mu \mathrm{m}$

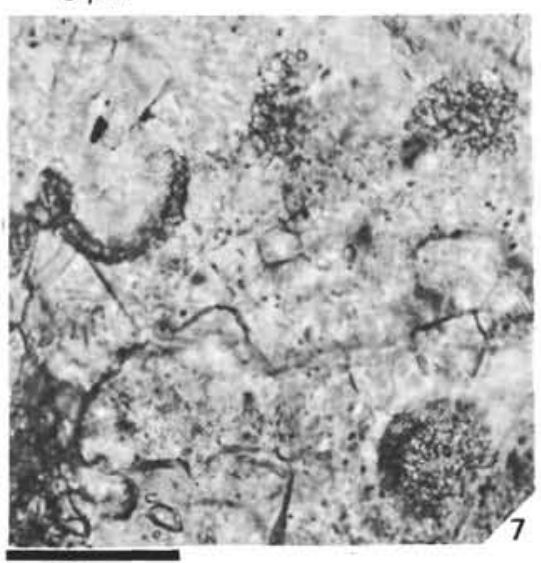

$30 \mu \mathrm{m}$

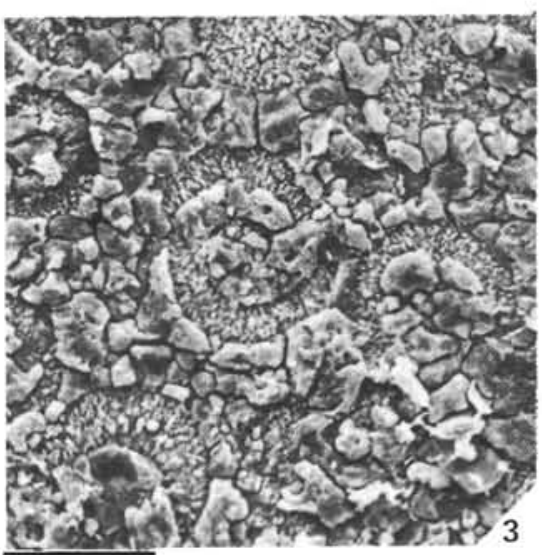

$20 \mu \mathrm{m}$

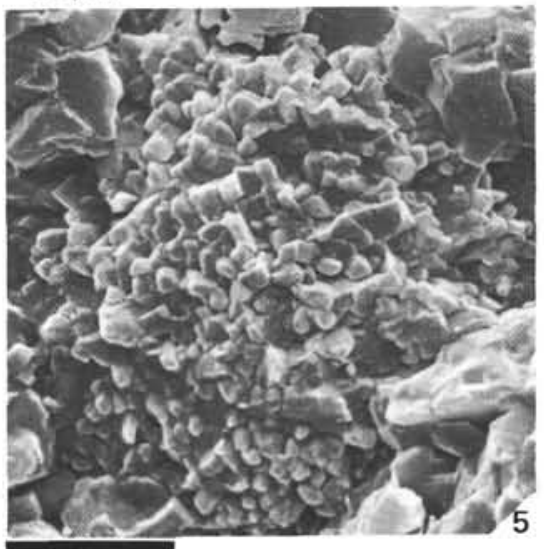

$5 \mu \mathrm{m}$

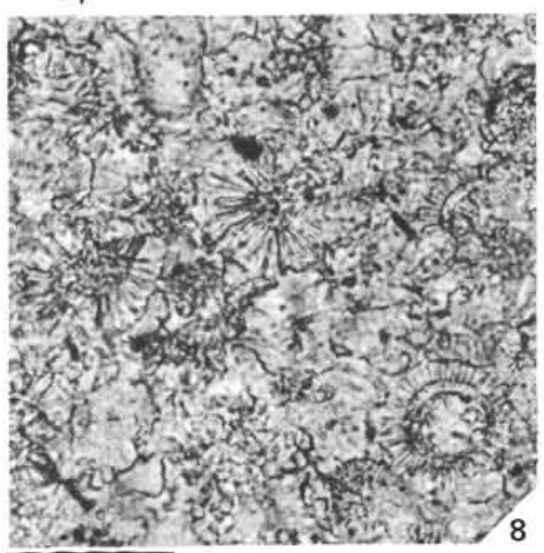

$30 \mu \mathrm{m}$

Plate 4. Schizosphaerella astrea; preservation in Tethyan Lower Jurassic cephalopod/crinoid limestone. 1. Pelleted texture of phragmocone-filling sediment in ammonite. Dark clots are largely single valves of $S$. astrea. Light interstitial (micro)spar originated in part with early seafloor cementation and in part with later neomorphism of carbonate mud. Vertical textural variations may reflect varying depositional rates, enhancing the importance of passively precipitated cement during phases of slower accretion or nondeposition. Thin section, plane light. 2-3. Microtexture of same sediment as in Fig. 1; overview SE micrographs of fresh broken (2) and polished and slightly etched (3) rock surfaces. 4-6. Cross sections with stacked, dominantly rhomb-shaped crystals $(4,6)$ and characteristic serrated surface pattern (Fig. 4, inner surface; Fig. 5, outer surface) of fully cemented valve specimens of $S$. astrea. SE micrographs. 7-8. Appearance of $S$. astrea (7) in thin section at higher magnifications as compared with $S$. punctulata (8). Note generally larger dimension of $S$. astrea and lack in the same species of a fringing radially structured crust of diagenetic calcite. 1-7. Rosso Ammonitico Țoscano (lower part), upper Sinemurian, Monte Cetona, southeastern Tuscany, central Italy; Fig. 8. Calcare Selcifero, upper Pliensbachian, same location. 

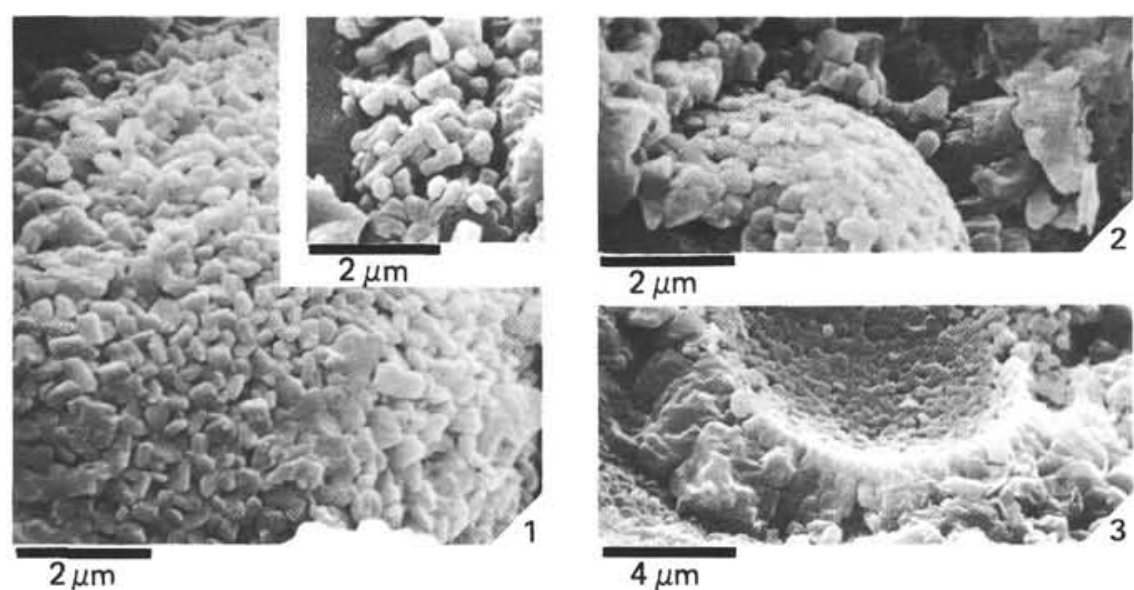

$4 \mu \mathrm{m}$
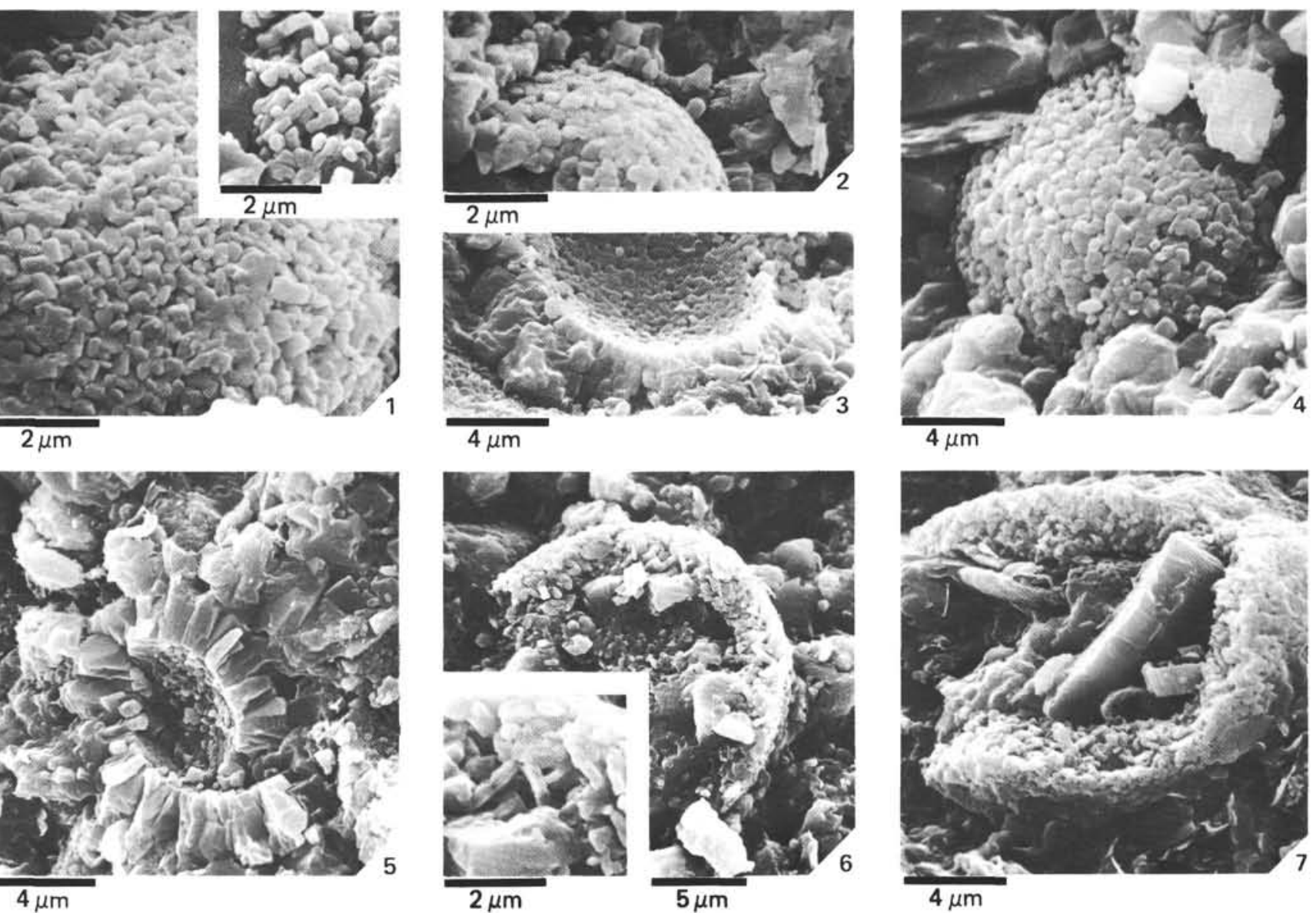

Plate 5. Preservation of Schizosphaerella, Jurassic lithologies, Hole 547B. SE micrographs of fresh broken rock surfaces. Figs. 1-5 illustrate modes of preservation of S. punctulata; Figs. 6-7, S. astrea. 1. Surface pattern and valve cross section (inset) of specimen in advanced stage of intraskeletal cementation. Elementary tabular calcite crystallites are markedly thickened as a result of diagenetic syntaxial overgrowth. Note characteristic interpenetration of crystallites in inset. Sample 547B-23-2, 39-41 cm, inset, Sample 547B-15-1, 109-111 cm. 2. Heavily overgrown valve specimen with smoothed outer valve surface overlain by thin fringe of equant crystals of diagenetic calcite (compare Pl. 3, Fig. 3). Sample 547B$23-2,39-41 \mathrm{~cm}$. 3. Crust of equant diagenetic calcite crystals spalled off from the foundation during sample preparation. Smooth interfaces between cemented valves of $S$. punctulata and fringing radially structured crusts are the preferred parting planes when rock is broken (see also Fig. 5 and various examples on Pls. 2,3). Sample 547B-16-2, 126-128 cm. 4. Diagenetically strongly altered valve surface with virtual obliteration of any primary ultrastructural feature due to expansion of overgrowth beyond the original skeletal surface (compare Pl. 3, Fig. 3). Sample 547B-16-2, 126-128 cm. 5. Spalled fringe of radially arranged bladed diagenetic calcite (compare Pl. 3, Fig. 4). Sample 547B-23-2, 39-41 cm. 6. Broken hemispherical valve of $S$. astrea. Moderate degree of diagenetic alteration allows recognition of internal structural details (inset). As predicted by the respective models in $\mathrm{Pl}$. 1, no intergrowth between the fundamental lamellar skeletal elements is observed (contrast with inset in Fig. 1; Pl. 2, Fig. 2). Sample 547B-15-2, 71-73 cm. 7. Moderately altered valve specimen of $S$. astrea (from claystone) having undergone perceptible compactive deformation. Deformation of the skeletal framework by mechanical compaction may be favored in $S$. astrea by the specific ultrastructural organization with no interpenetration normally occurring between the elementary crystallites. Note small coccolith within valve. Sample 547B-22-2, 30-34 cm. 

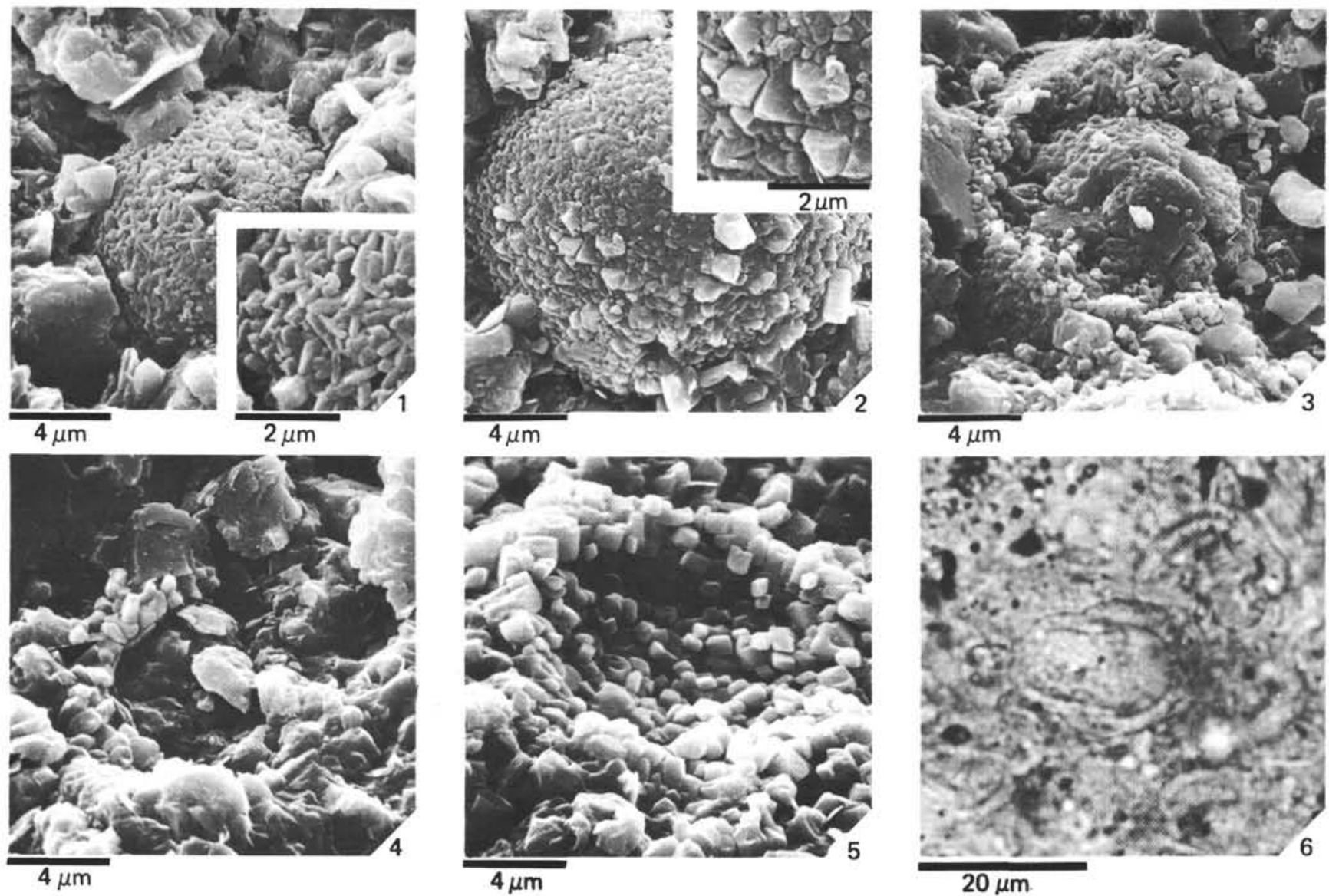

Plate 6. Preservation of Schizosphaerella, Jurassic lithologies, Hole 547B, continued. SE micrographs of fresh broken rock surfaces; Fig. 6, thin section micrograph. 1. S. astrea, segment of valve surface, diagenetically moderately altered specimen. Lamellar calcite crystallites constituting the skeletal framework are thickened and the original skeletal voids partially occluded by syntaxial overgrowth cement. Sample 547B-15-1, 109$111 \mathrm{~cm}$. 2. S. astrea, surface aspect of specimen in an advanced stage of diagenetic alteration. Initial surface morphology is largely smoothed due to deposition of secondary overgrowth cement within surficial cavities and, locally, cement crystals extend beyond the original valve surface. Note three-sided pyramidal terminations of some epitaxial cement projections (inset). Continued overgrowth may result in the ragged surface pattern shown in Pl. 4, Fig. 5. Sample 547B-15-1, 109-111 cm. 3. Fractured valve specimen of $S$. astrea with the intraskeletal voids largely occluded by syntaxial overgrowth cement. The fabric observed may be transitional to that shown in Pl. 4, Figs. 4, 6. Coarse crystals of blocky calcite occupying the central void space of the valve replicate the diagenetically altered surface pattern. Sample $547 \mathrm{~B}-17-1,79-83 \mathrm{~cm}$. 4 . Valve cross section revealing fabric resulting from complete intraskeletal cementation. Judging from shape and mutual arrangement of the constituent crystals (both suggestive of intergrowth between their lamellar precursors, see arrow) and the smooth contact with surrounding micrite and microspar, the specimen is most probably referable to $S$. punctulata (compare Pl. 3, Figs. 4, 5). A rim of diagenetic radial fibrous or bladed calcite does not necessarily develop (see text). Sample 547B-11-4, 118-120 cm, component of micro-breccia. 5. Relic of fully cemented valve specimen. Breakage during sample preparation caused the tight diagenetic fabric of overgrown skeletal elements to largely disintegrate, resulting in an accumulation of loosely packed and randomly oriented, about micron-sized, crystals, frequently delimited by rhombohedral faces. Sample 547B-11$3,92-94 \mathrm{~cm}$, component of micro-breccia. 6. Thin section micrograph of double-valved specimen of $S$. astrea. Note characteristic hingement with simple overlapping valves. A slight compactional deformation of the specimen normal to the long axis of the skeleton is suggested when compared to Moshkovitz's holotype (1979, pl. 2, Fig. 1. See also Pl. 5, Fig. 7 and Pl. 6, Fig. 4). Sample 547B-22-2, 30-34 cm. 


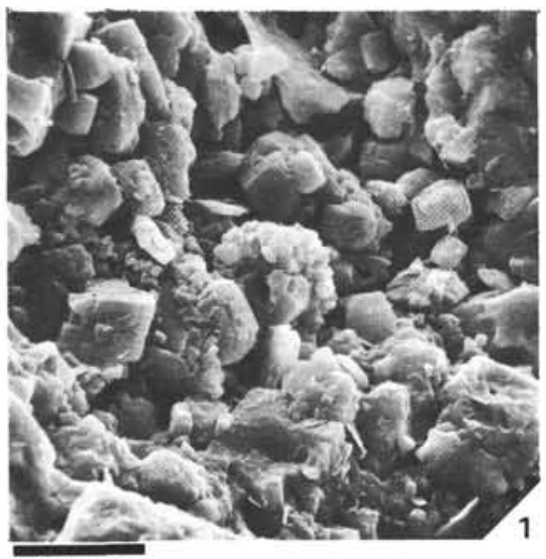

$10 \mu \mathrm{m}$

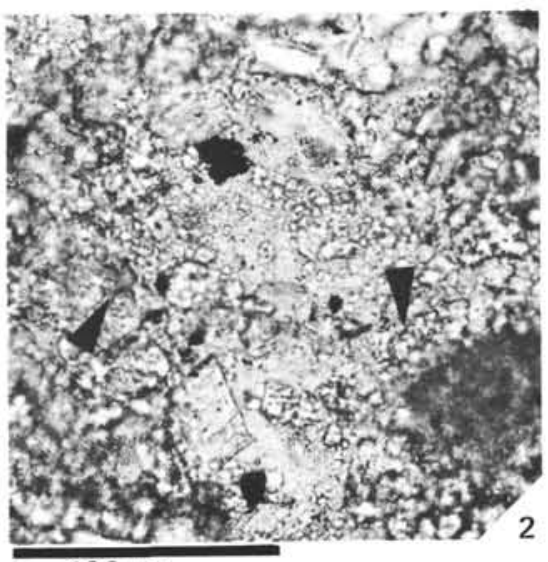

$100 \mu \mathrm{m}$

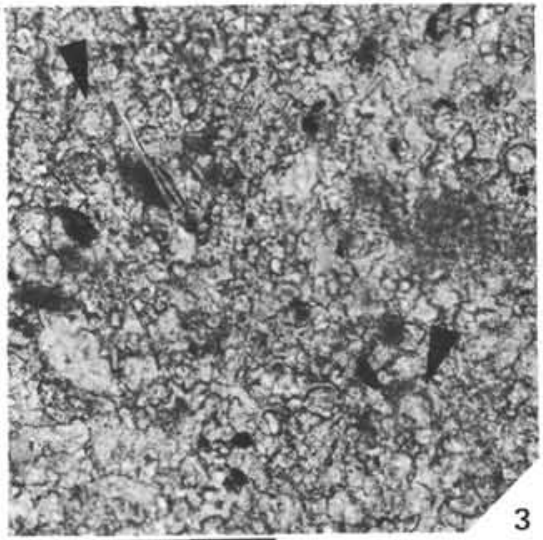

$100 \mu \mathrm{m}$

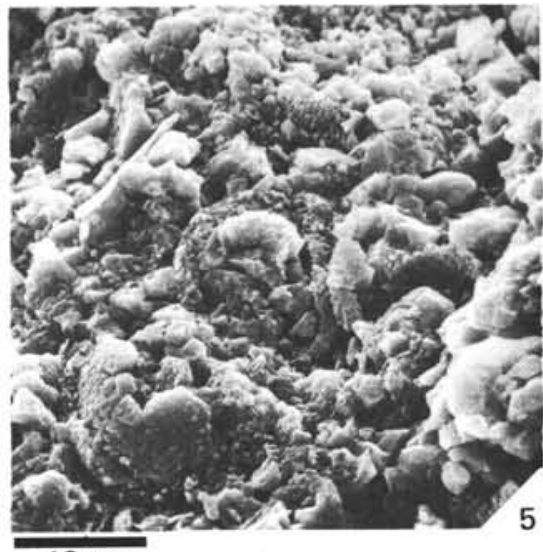

$10 \mu \mathrm{m}$

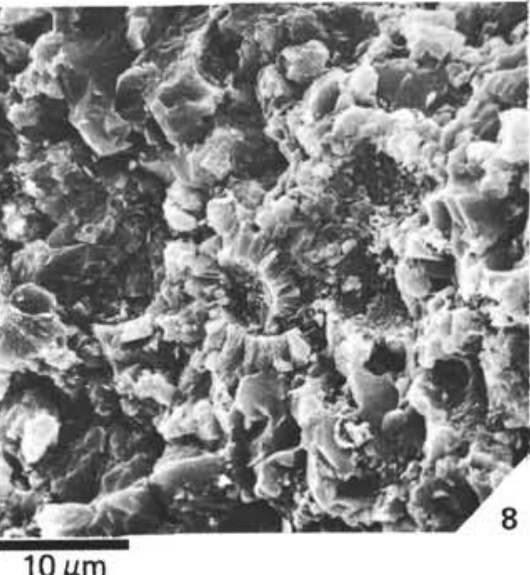

$10 \mu \mathrm{m}$

$10 \mu \mathrm{m}$

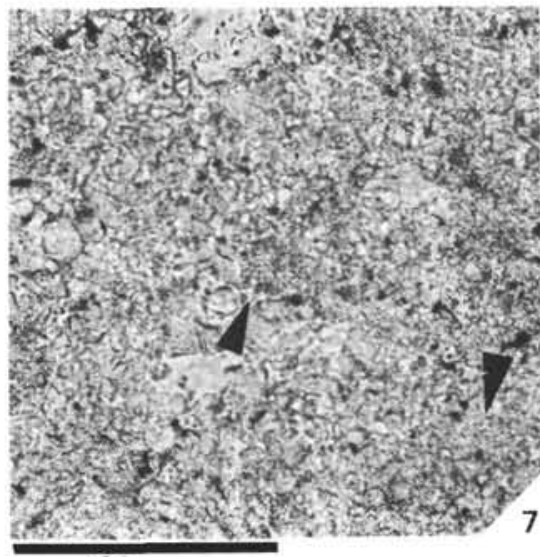

$100 \mu \mathrm{m}$

Plate 7. Microtexture of representative lithologic types, Lower to Middle Jurassic, Hole 547B; combined overview SE and thin section micrographs. 1-2. Matrix of nodular limestone; mosaic of polyhedral neomorphic microspar containing heavily overgrown schizosphaerellid skeletons and skeletal debris. Rhombohedral crystals are dolomite. Fig. 2, lower right, part of small micrite nodule. Sample 547B-10-3, 0-3 cm. 3, 5. Matrix of reddish-brown nodular limestone; inequigranular fabric of microspar, probably largely of neomorphic origin, with relic micrite patches and many schizosphaerellids, especially S. astrea (see also Pl. 6, Figs. 1, 2). Bulk sample X-ray analysis revealed, apart from prevailing stable low-Mg calcite $\left(<1 \mathrm{~mol} \% \mathrm{MgCO}_{3}\right)$, minor quantities of a Mg-bearing calcite (with approx. $6 \mathrm{~mol} \% \mathrm{MgCO}_{3}$, ?cement). Sample 547B$15-1,109-111 \mathrm{~cm} . \quad$ 4, 6. Gray-greenish siliclastic detritus-bearing claystone rich in Schizosphaerella, in particular, S. astrea. Note tendency toward alignment parallel to bedding and, in certain cases, perceptible compactive deformation of valves in the thin section micrograph (4) and wrappings of clay minerals around skeletons and skeletal debris in the SE micrograph (6) (see also Pl. 5, Fig. 7; Pl. 6, Fig. 6). Sample 547B-22-2, 30-34 cm. 7-8. Gray limestone. Schizosphaerellid skeletal fragments appear scattered through a mosaic of micrite and anhedral microspar. Specimens of the species $S$. punctulata in this lithology are commonly overlain by more or less developed radially structured fringes of diagenetic calcite (see also close-up Pl. 5, Fig. 5). Bulk sample X-ray analysis revealed a stable calcite mineralogy (2.5-3 mol $\left.\% \mathrm{MgCO}_{3}\right)$. Sample 547B-23-2, $39-41 \mathrm{~cm}$. Arrows in thin section micrographs in Figs. 2, 3, and 7 indicate schizosphaerellids. 


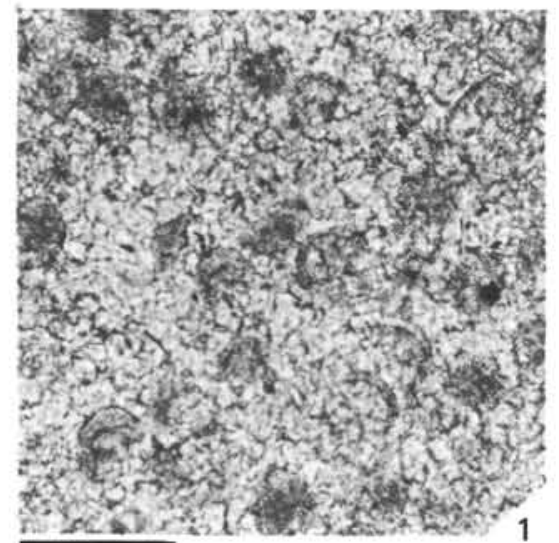

$50 \mu \mathrm{m}$

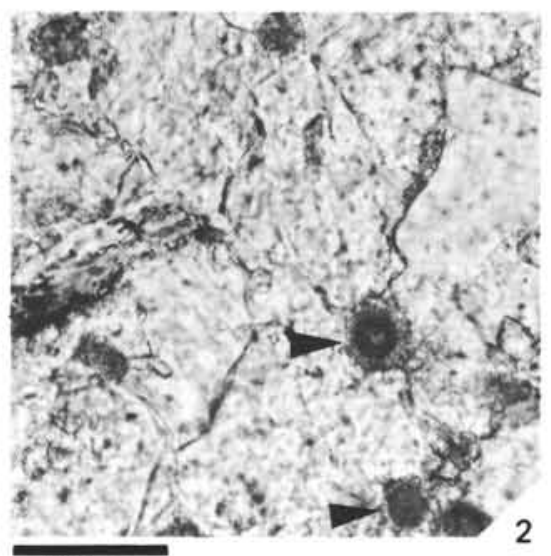

$50 \mu \mathrm{m}$

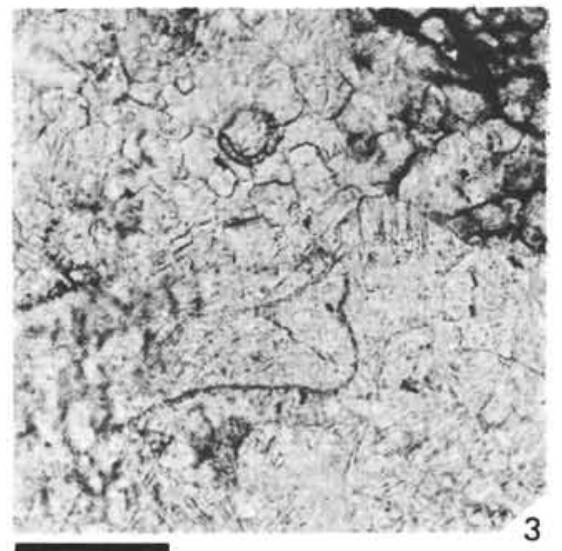

$50 \mu \mathrm{m}$

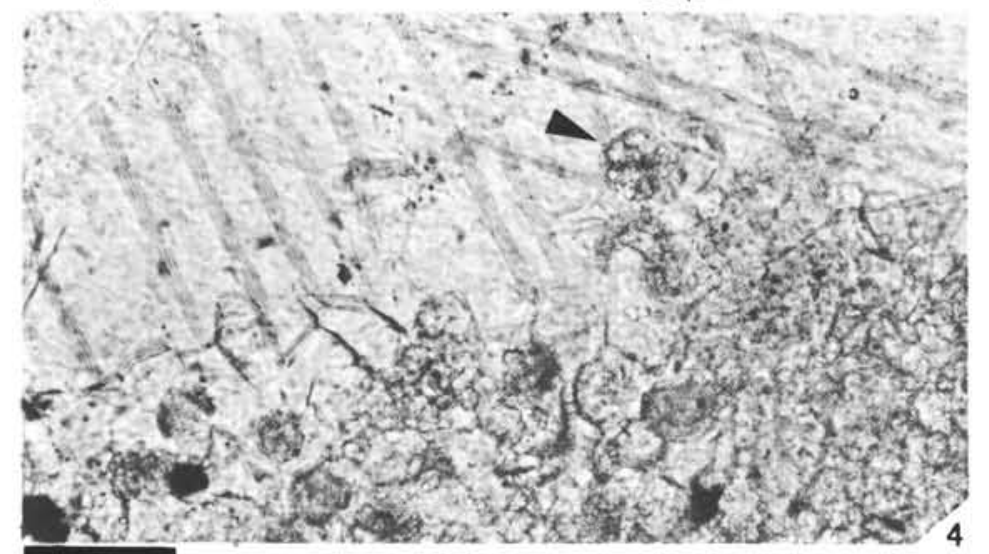

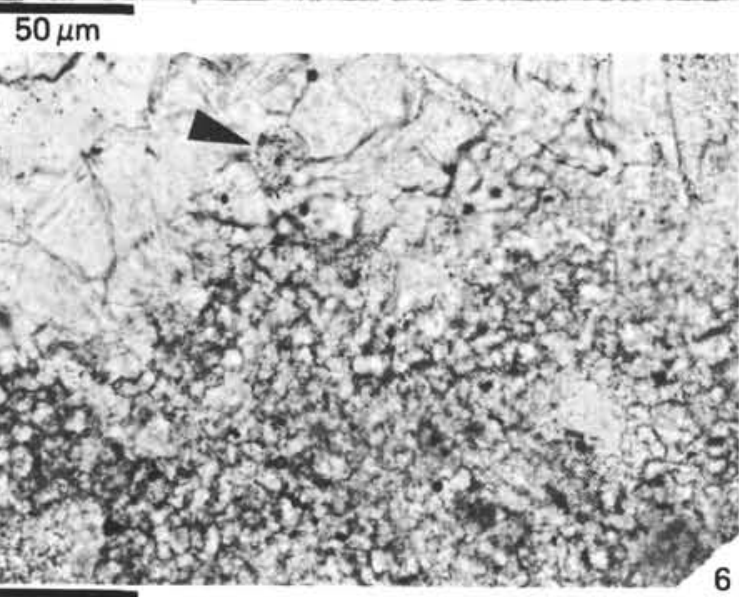

$50 \mu \mathrm{m}$

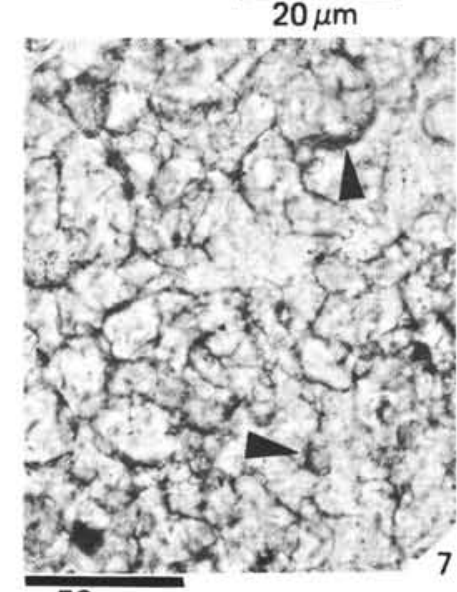

$50 \mu \mathrm{m}$

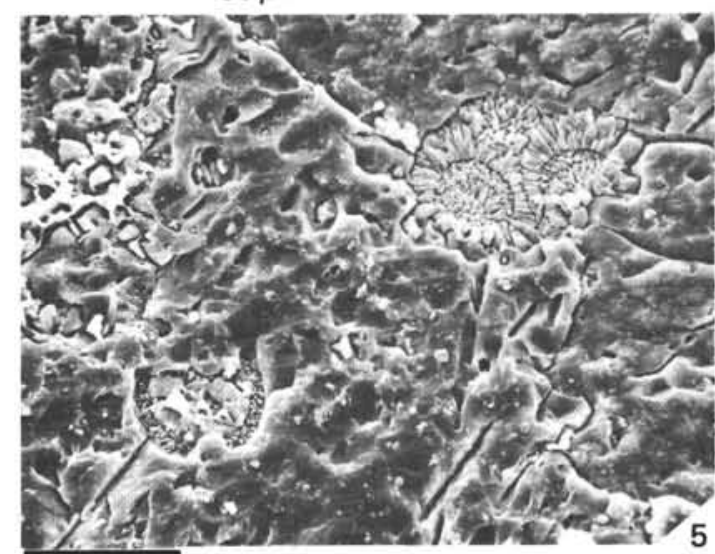

$20 \mu \mathrm{m}$

Plate 8. Schizosphaerella as relic inclusions in fabrics of neomorphic (micro)spar. Figs. 1-4, 6-8, thin section micrographs; Fig. 5, SE micrograph of polished and slightly etched rock surface. Figs. 1, 3, 4, from Rosso Ammonitico Toscano (lower part), upper Sinemurian, Monte Cetona, southeastern Tuscany, central Italy. 1. Scattered, randomly oriented, single valves of $S$. astrea (Pl. 4, Figs. 2-7) in a groundmass of anhedral tightly interlocked microspar, presumably largely replacive of an earlier mechanically deposited micritic matrix. 2. Specimens of $S$. punctulata with more or less developed fringing crusts of bladed calcite (arrows) included ("floating relics") in coarse pseudospar mosaic. It is very unlikely that the fringes would have succeeded in expanding against the coarse neomorphic spar, so an earlier development must be inferred; selective preservation, in turn, points to highly stable fabrics. Lower Middle Jurassic, Breggia Valley, Lombardian Zone, southern Alps, southern Switzerland. 3. Specimens of $S$. astrea embedded in neomorphic (micro)spar. Patchy sparry replacement of fine-grained interstitial sediment in clastsupported breccia, filling small dykes in condensed cephalopod/crinoid limestone. Note "ghost" of molluscan shell fragment in the sparry calcite mosaic. 4, 6. Boundaries between pore-filling sparry cement and geopetal sediment in sheltered cavities, (4) chamber of ammonite, (6) frame interstice in clast-supported lime breccia. Original micrite has altered to microspar or been replaced through enlargement (downward) of sparry calcite crystals occupying the original void space, as shown by included valves of Schizosphaerella (mainly of $S$. astrea, see arrows). Fig. 6, Sample 547B-22-2, 74-76 cm. 5. Clustered valves of $S$. punctulata with thick radially structured envelopes included in neomorphic spar (compare Fig. 2). Larger nonrimmed specimen is most probably referable to $S$. astrea. Morbio Formation, upper Pliensbachian, Breggia Valley, Lombardian Zone, southern Alps, southern Switzerland. 7-8. Details of fabrics of anhedral neomorphic microsparite (8) to sparite (7) with common included schizosphaerellids (arrows). Note exceptionally large specimen in Fig. 7. Matrix of reddish nodular limestone (compare Pl. 7, Figs. 3, 5). Sample 547B-15-1, 109-111 cm. 


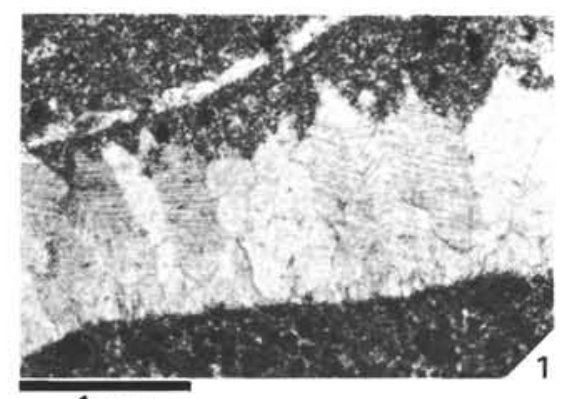

$1 \mathrm{~mm}$

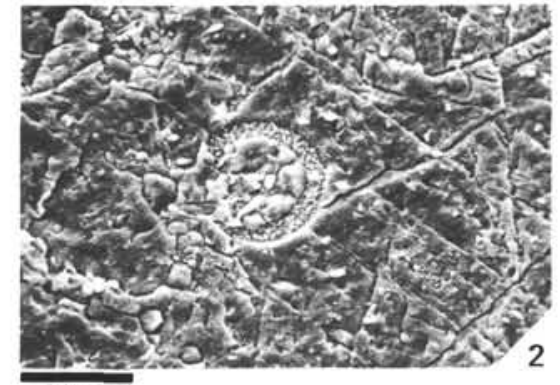

$20 \mu \mathrm{m}$
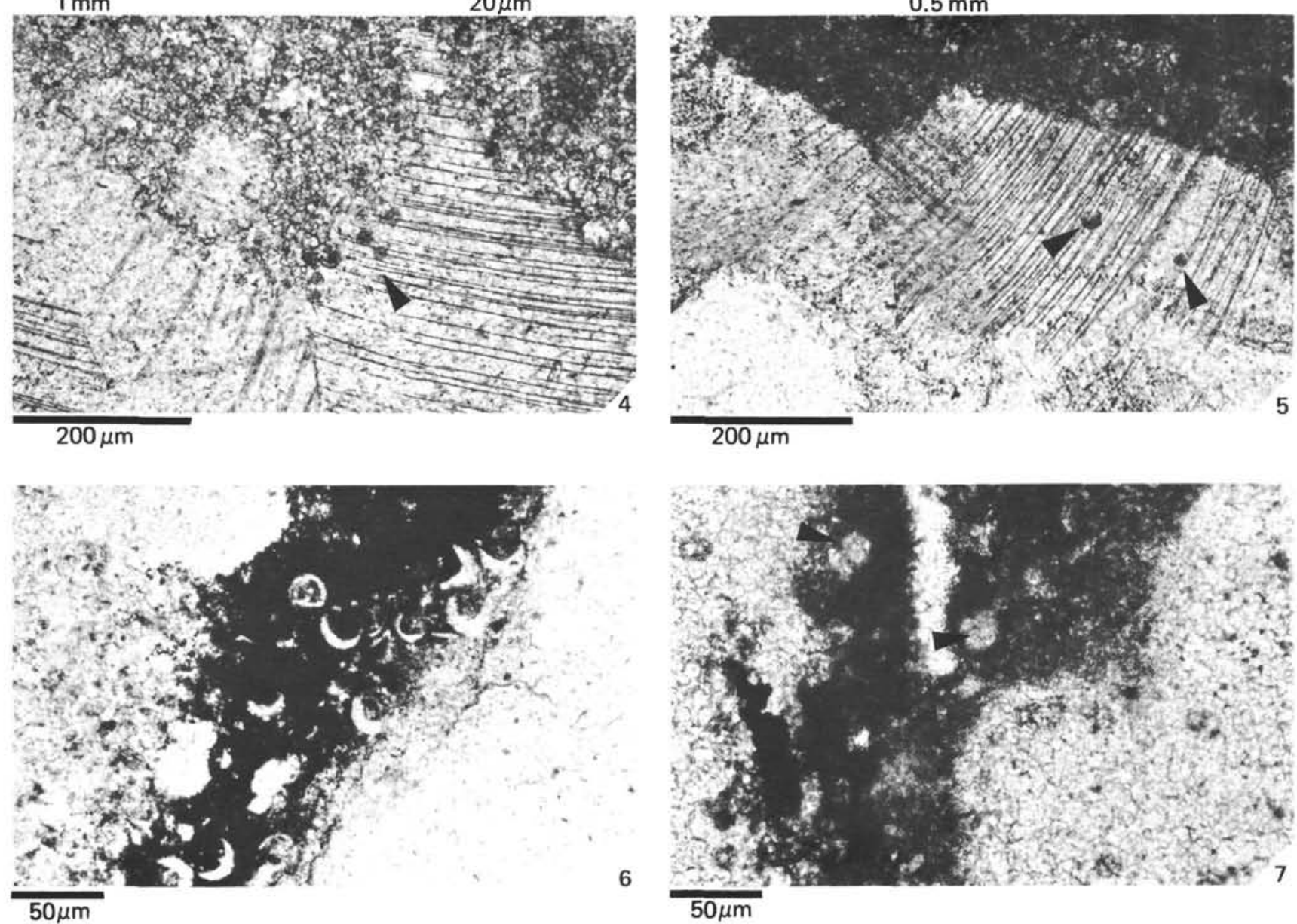

Plate 9. Schizosphaerellids as inclusions in radiaxial fibrous calcite (Figs. 1-5) and in surficial iron-(hydr)oxide coatings (Figs. 6-7). Figs. 1, 3-7, thin section micrographs; Fig. 2, SE micrograph of polished and slightly etched rock surface. 1. Intervening radiaxial fibrous calcite rim (replacive of an earlier acicular cement; Kendall and Tucker, 1973) between shallow-water limestone clast (below) and younger red pelagic carbonate sediment (above); (detail of pl. 1, fig. 1 in Bernoulli and Kälin, this volume). Rosso Ammonitico Toscano (lower part), Sinemurian, Monte Cetona, southeastern Tuscany, central Italy. 2. Valve specimen of $S$. astrea included in radiaxial fibrous calcite. Same sample as in Fig. 1 . 3. Ammonite septum rimmed by partially silica-replaced, radiaxial fibrous calcite. The fabric suggests a complex sequence of diagenetic events: (a) growth on the aragonitic septum of an acicular cement fringe (?magnesian calcite) on the seafloor; (b) burial and geopetal (not visible) deposition of normal hemipelagic lime mud (dark zone at right) in remnant chamber cavities; (c) leaching of skeletal aragonite and filling of septal mold with muddy sediment; (d) replacement of acicular early cement by radiaxial fibrous calcite; (e) syntaxial neomorphic extension of radiaxial fibrous calcite and growth of microspar under replacement of chamber- and mold-filling sediment, respectively; and (f) partial replacement of radiaxial fibrous calcite and neomorphic microspar by length-slow chalcedony (white patches). Dark clots in mold-filling microspar are valves of $S$. astrea. Corso Bianco, upper Sinemurian, Botticino, Lombardian Zone, southern Alps, northern Italy. 4. Close-up of Fig. 1. Junction between radiaxial fibrous calcite and overlying internal sediment. Included schizosphaerellids (arrow) point to a sediment-replacive origin of the terminal spires of the radiaxial fibrous calcite crystals. 5. Detail from partially silica-replaced, radiaxial fibrous calcite rim shown in Fig. 3. Enclosed valves of Schizosphaerella (arrows) are either relics of entrapped interacicular sediment in the precursor cement fabric or, alternatively, distal portions of radiaxial fibrous calcite crystals are entirely of sediment-replacive origin. 6-7. Schizosphaerellids (in Fig. 6, S. astrea) enclosed in surficial iron(hydr)oxide coatings on biomicrite clasts (now largely microspar) (6) component of matrix-poor breccia (void-filling spar at right), Rosso Ammonitico Toscano (lower part), upper Sinemurian, Monte Cetona, southeastern Tuscany, central Italy; (7) Sample 547B-8-1, 15-17 cm. 

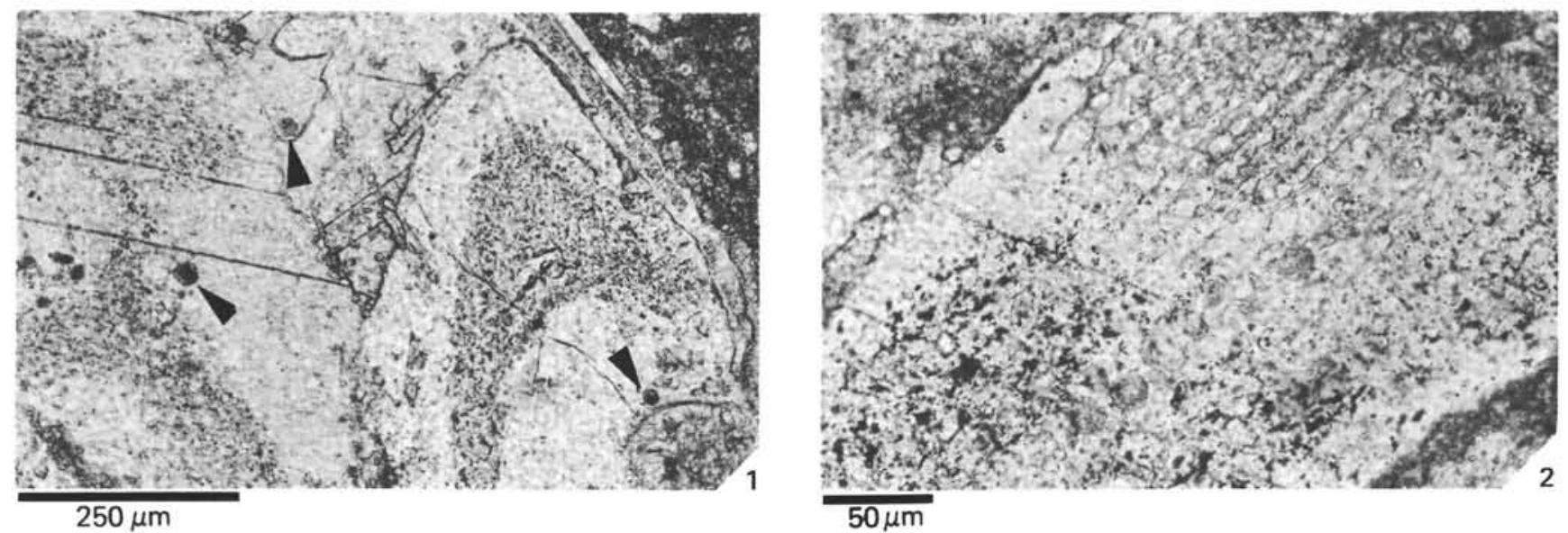

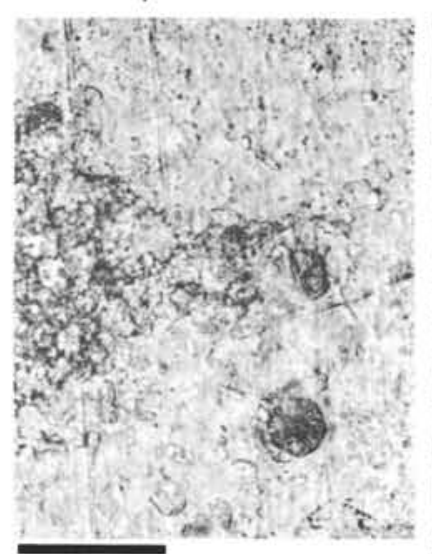

$50 \mu \mathrm{m}$

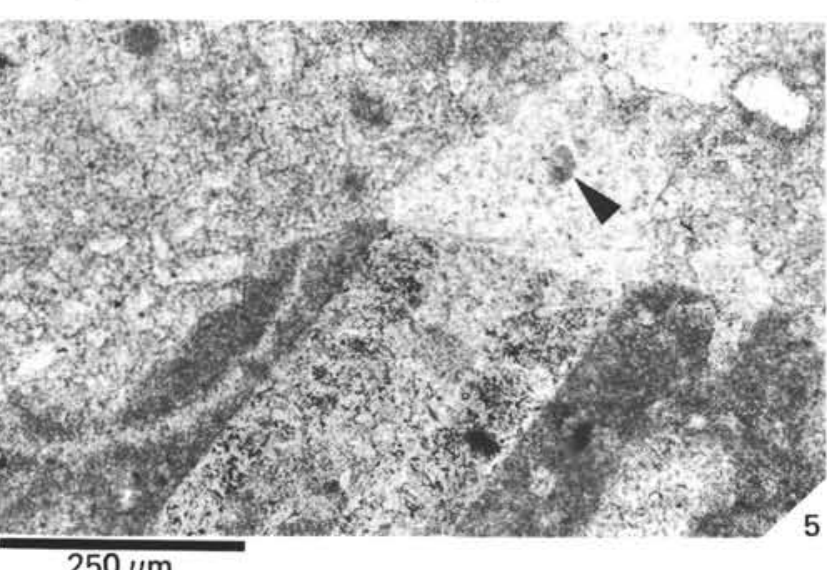

$50 \mu \mathrm{m}$
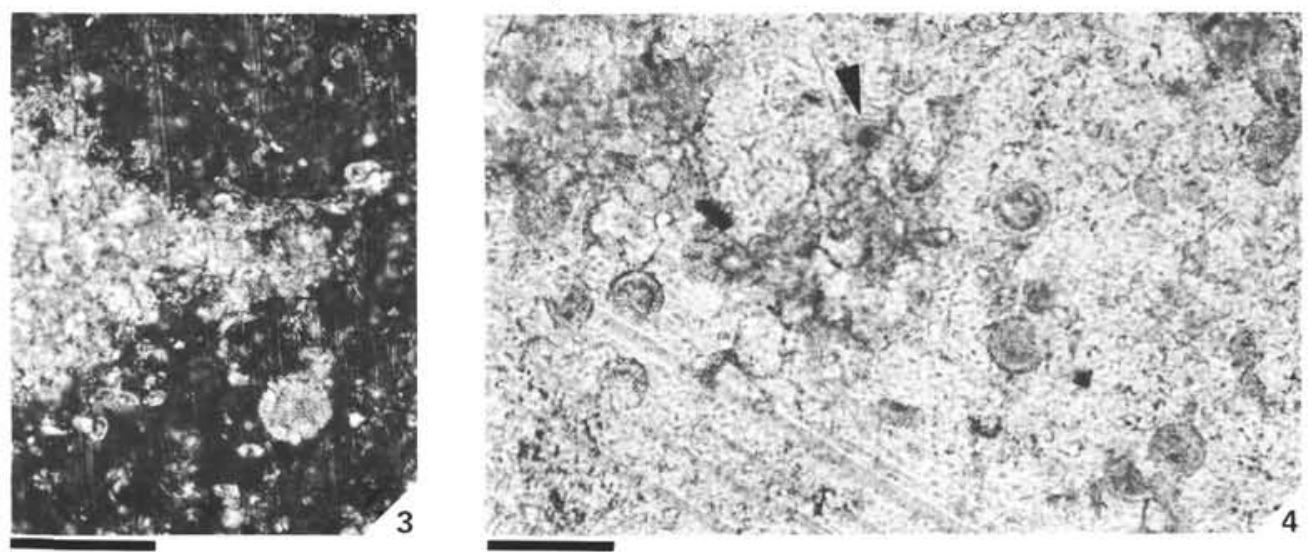

$50 \mu \mathrm{m}$

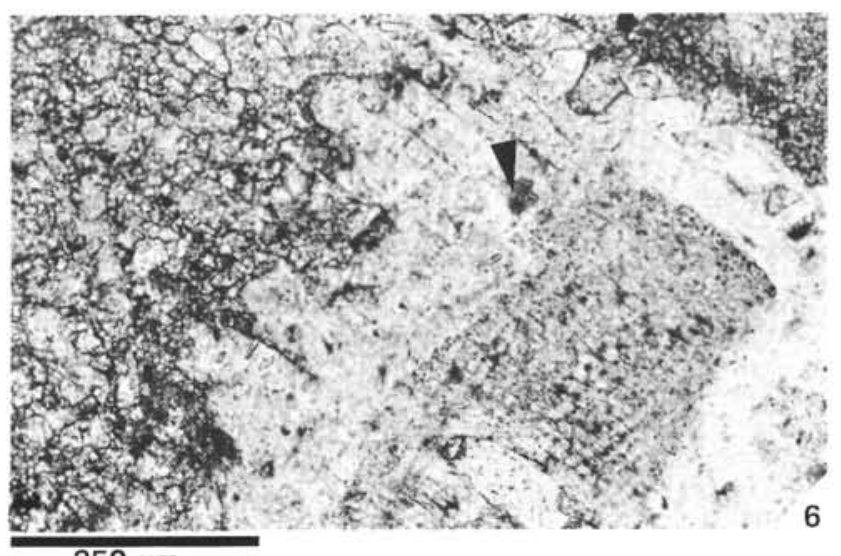

$250 \mu \mathrm{m}$

Plate 10. Schizosphaerellids enclosed in neomorphic syntaxial rims around echinoderm debris, thin section micrographs. 1. Clustered echinodermal skeletal fragments (dark speckled areas) with large interfering syntaxial calcite rims (light) with sparse included schizosphaerellids (arrows) embedded in fine-grained matrix (upper right corner); host rock is a greenish nodular limestone (biomicrite). 2. Ossicle with central canal traced by preserved valves and valve debris of Schizosphaerella. Other fine-grained sediment components, presumably contributing to the original infill, probably became obliterated during diagenesis with replacive syntaxial extension of the skeletal fragment. Note thin streaks of lightcolored syntaxial neomorphic calcite delimiting the ossicle laterally against the surrounding sediment. 3. Specimen of $S$. punctulata with an overlying thick fringe of radially arranged calcite prisms enclosed in a "saw-toothed" syntaxial neomorphic rim (left, plane light; right, crossed nicols). Favored by its shape and large dimension (Neugebauer, 1974), echinodermal debris is generally thought to start enlarging earlier during diagenesis and at higher rates than most other types of grains (e.g., Bathurst, 1975), yet growth of the fringe around $S$. punctulata had to be virtually completed (isopachous development excludes competitive growth, see also PI. 8, Fig. 2) at the time of its inclusion. 4. Specimens of S.astrea and rimmed specimen of $S$. punctulata (arrow) included in syntaxial neomorphic spar irregularly replacing surrounding micrite and matrix sediment infilled within surficial borings in echinoderm fragment. 5, 6. Syntaxial neomorphic extensions of ossicles into adjacent microspar. Echinoderm fragment in Fig. 6 is a component of a biomicrite clast in a lime breccia. Included schizosphaerellids are indicated by arrows. (5) Sample 547B-8-4, 43-46 cm; (6) Sample 547B-12-2, 25-28 cm. Figs. 1, 3, from Morbio Formation, upper Pliensbachian, Val Cepelline (Alta Brianza), Lombardian Zone, southern Alps, northern Italy. Figs. 2, 4, from Medolo Formation, upper Pliensbachian, Botticino, Lombardian Zone, southern Alps, northern Italy. 

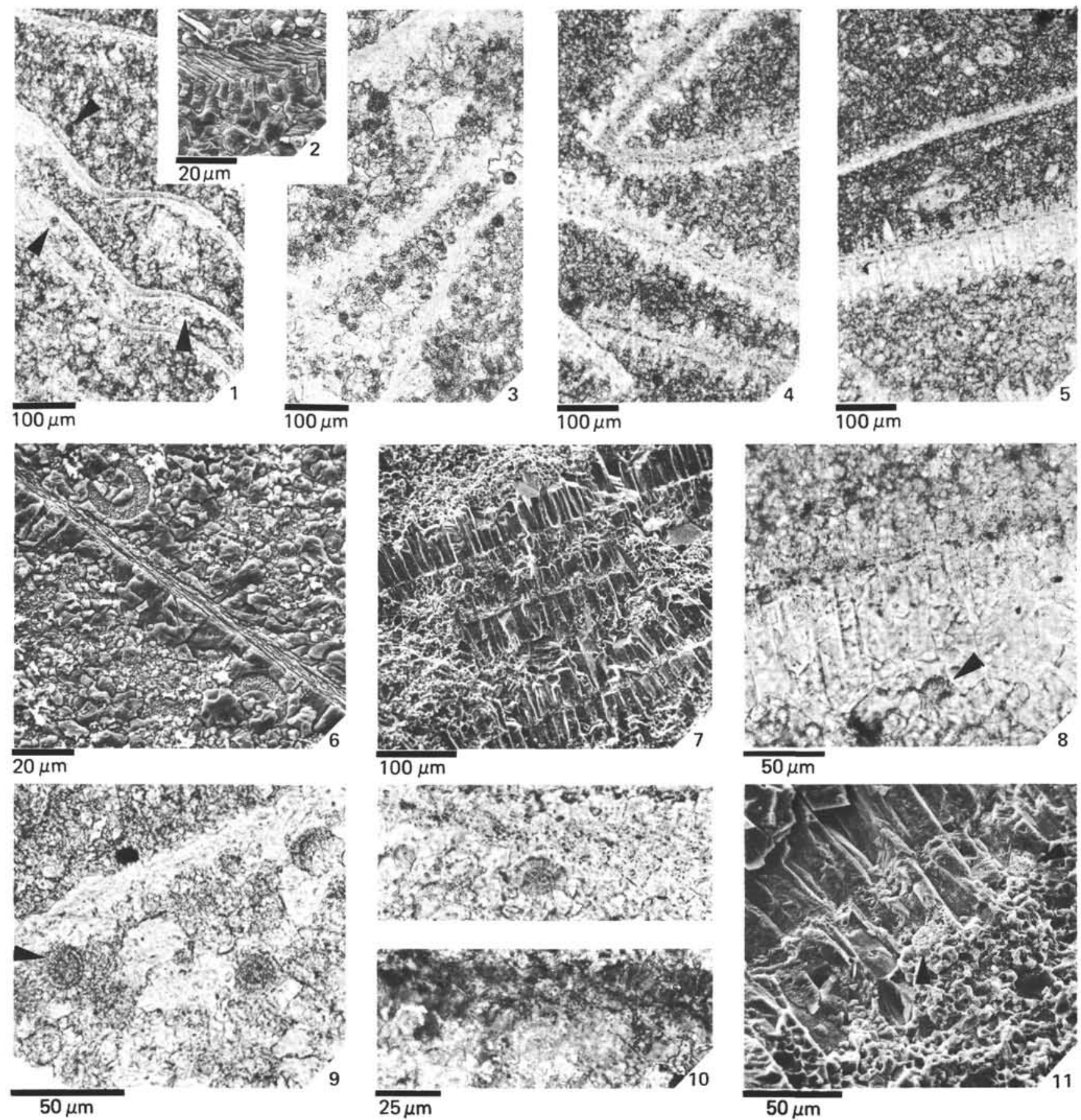

Plate 11. Schizosphaerellids enclosed in polycrystalline neomorphic rims grown out syntaxially from thin-shelled "pelagic" bivalves or their debris.

Figs. 1, 3-5, 8-10, thin section micrographs; Figs. 2, 6, SE micrographs of polished and slightly etched rock surfaces; Figs. 7, 11. SE micrographs of fresh broken rock surfaces. 1. Overgrown valve relics (Fig. 2) of Bositra set in a mosaic of neomorphic microspar with scattered included schizosphaerellids (dark clots, arrows). Light-colored syntaxial extensions are in part true void-filling cement (sheltered cavities, left side) and in part of replacement origin, as shown by enclosed schizosphaerellids. Bositra lumachella. Marne a Posidonia (lower part), ?uppermost Liassic/ lower Middle Jurassic, Monti di Poggiano, southeastern Tuscany, central Italy. 2. Overgrown valve relic of Bositra. Only a single shell layer with oblique lamellar microstructure is preserved. Neomorphic syntaxial extensions of the skeletal crystallites are oriented perpendicular to the valve surface. Same sample as Fig. 1. 3-5, 8.Morphology of polycrystalline neomorphic syntaxial rims on undetermined forms of thin-shelled "pelagic" bivalves. Groundmass is largely neomorphic microspar. Dark clots, particularly abundant in Fig. 3 are valves of Schizosphaerella. (8) detail of Fig. 5, arrow points to valve of Schizosphaerella in distal part of neomorphic syntaxial rim. (3) Sogno Formation, upper Toarcian/lower Middle Jurassic, Burligo, Lombardian Zone, southern Alps, northern Italy; (4, 5) Sample 547B-8-3, 54-57 cm. 6. Overgrown valve relic of undetermined thin-shelled "pelagic" bivalve with partially enclosed valves of $S$. astrea in irregularly developed neomorphic syntaxial rim. Note different microstructure of preserved shell layer with respect to Bositra (Fig. 2). Calcare del Domaro, lower Pliensbachian, Lonno, Lombardian Zone, southern Alps, northern Italy. 7, 11. Detailed morphology of polycrystalline neomorphic overgrowth on undetermined thin-shelled "pelagic" bivalves. Relic skeletal microstructure can not be discerned. Arrows in Fig. 11 indicate partially enclosed schizosphaerellids. Sample 547B8-3, 54-57 cm. 9, 10. (above, plane light; below, crossed nicols) Specimens of $S$. punctulata with overlying radially structured fringes enclosed or partially enclosed in neomorphic syntaxial rims on undetermined thin-shelled "pelagic" bivalves. Irregular development of fringing crusts on 

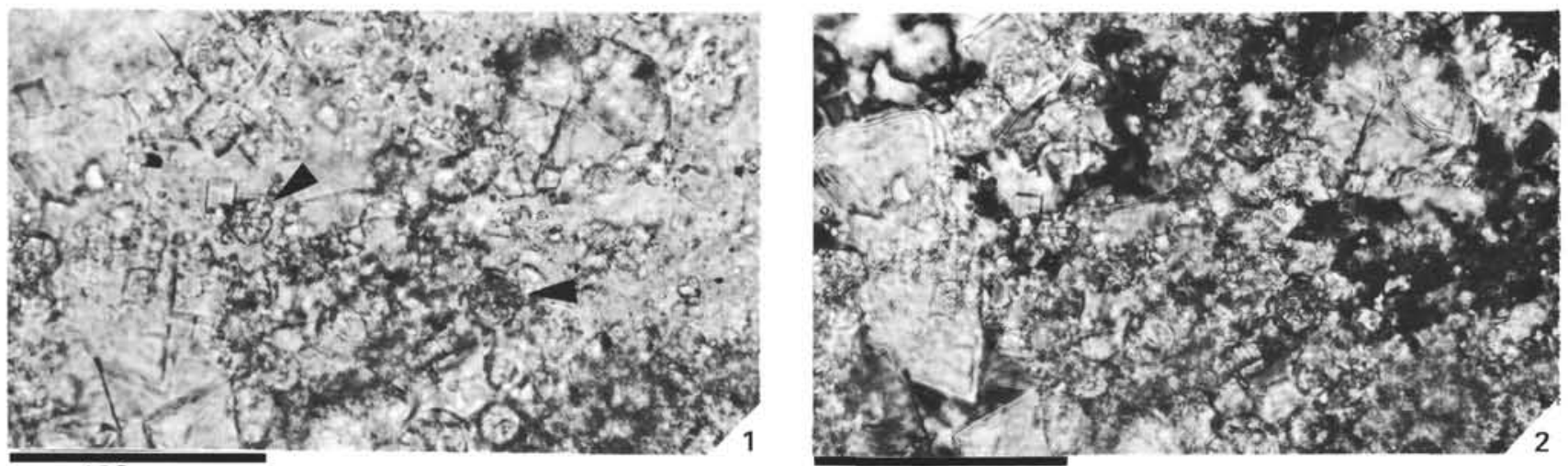

$100 \mu \mathrm{m}$

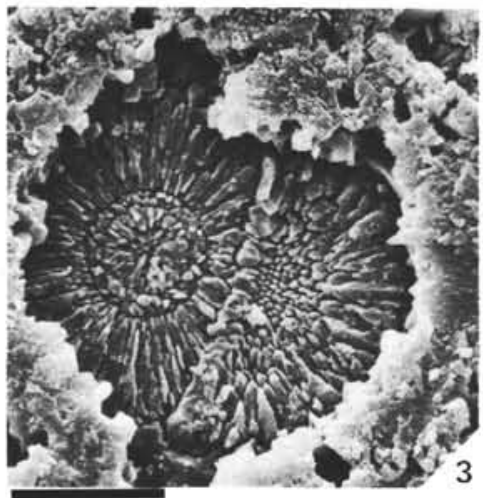

$10 \mu \mathrm{m}$

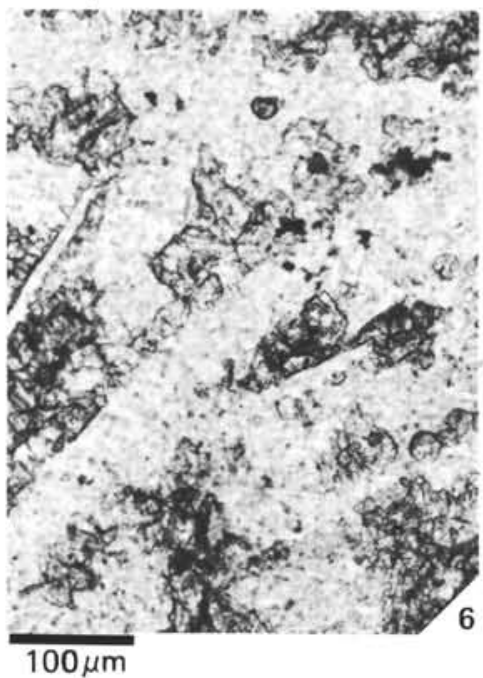

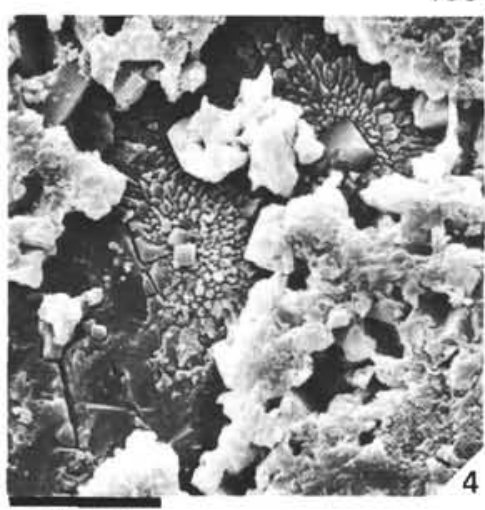

$10 \mu \mathrm{m}$

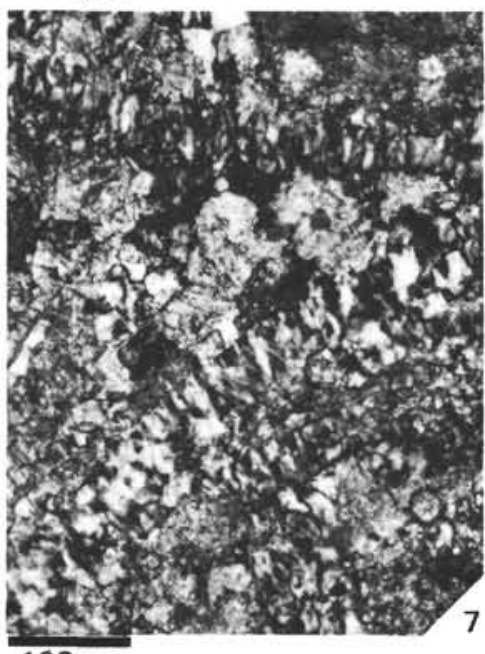

$100 \mu \mathrm{m}$

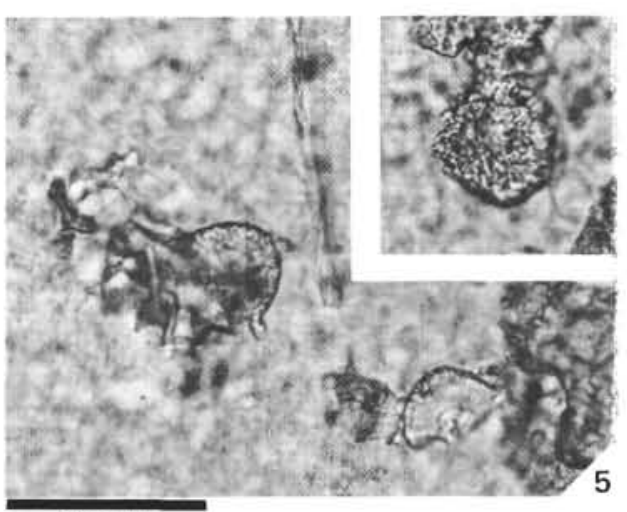

$50 \mu \mathrm{m}$

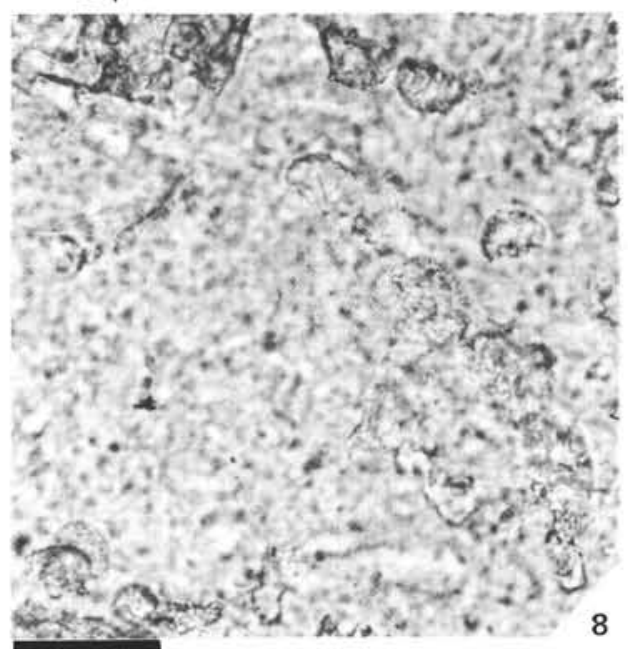

$50 \mu \mathrm{m}$

Plate 12. Schizosphaerella as relic carbonate inclusions in silica replacements. (Figs. 1, 2, 5-8, thin section micrographs; Figs. 3, 4: SE micrographs of polished and slightly etched rock surface.) 1 (plane light), 2 (crossed nicols) Marginal zone of quartz chert in basinal limestone. Silicification presumably initiated by precipitation of opal-CT within pores and partial replacement of original carbonate sediment during early intermediate diagenesis (Bernoulli, 1972; Riech and von Rad, 1979). Schizosphaerellids occur as individual inclusions and within larger included patches of (micro)spar (arrows). Rhombic calcite may be of late diagenetic origin (recrystallization and replacement of silica). Calcare del Domaro, Pliensbachian, Lonno, Lombardian Zone, southern Alps, northern Italy. 3, 4. Specimens of S. punctulata with overlying thick fringes of radially arranged calcite prisms enclosed by granular microquartz (replacement chert). Growth of fringes predates silicification. (4) tangential section of fringes; coarse blocky calcite in the lower left corner is probably of late diagenetic origin (see Fig. 1). Calcare Selcifero (upper part), upper Pliensbachian, Monte Cetona, southeastern Tuscany, central Italy. 5-8. Schizosphaerellids as relic carbonate inclusions within selectively silicareplaced (fibrous chalcedony, light-colored in Fig. 6) neomorphic syntaxial rims on thin-shelled "pelagic" bivalves (compare Pl. 11). (6) plane light, (7) crossed nicols; overviews. $(5,8)$ close-ups $(S$. punctulata); inset in Fig. 5 shows a rimmed specimen of $S$. punctulata. Late Toarcian, Breggia Valley, Lombardian Zone, southern Alps, southern Switzerland.

Plate 11. (Continued). S. punctulata, particularly evident in Fig. 9 (arrow), indicates simultaneous, competitive growth of the two neomorphic fabrics. (9) same sample as Fig. 3; (10) upper Toarcian, Breggia Valley, Lombardian Zone, southern Alps, southern Switzerland. 